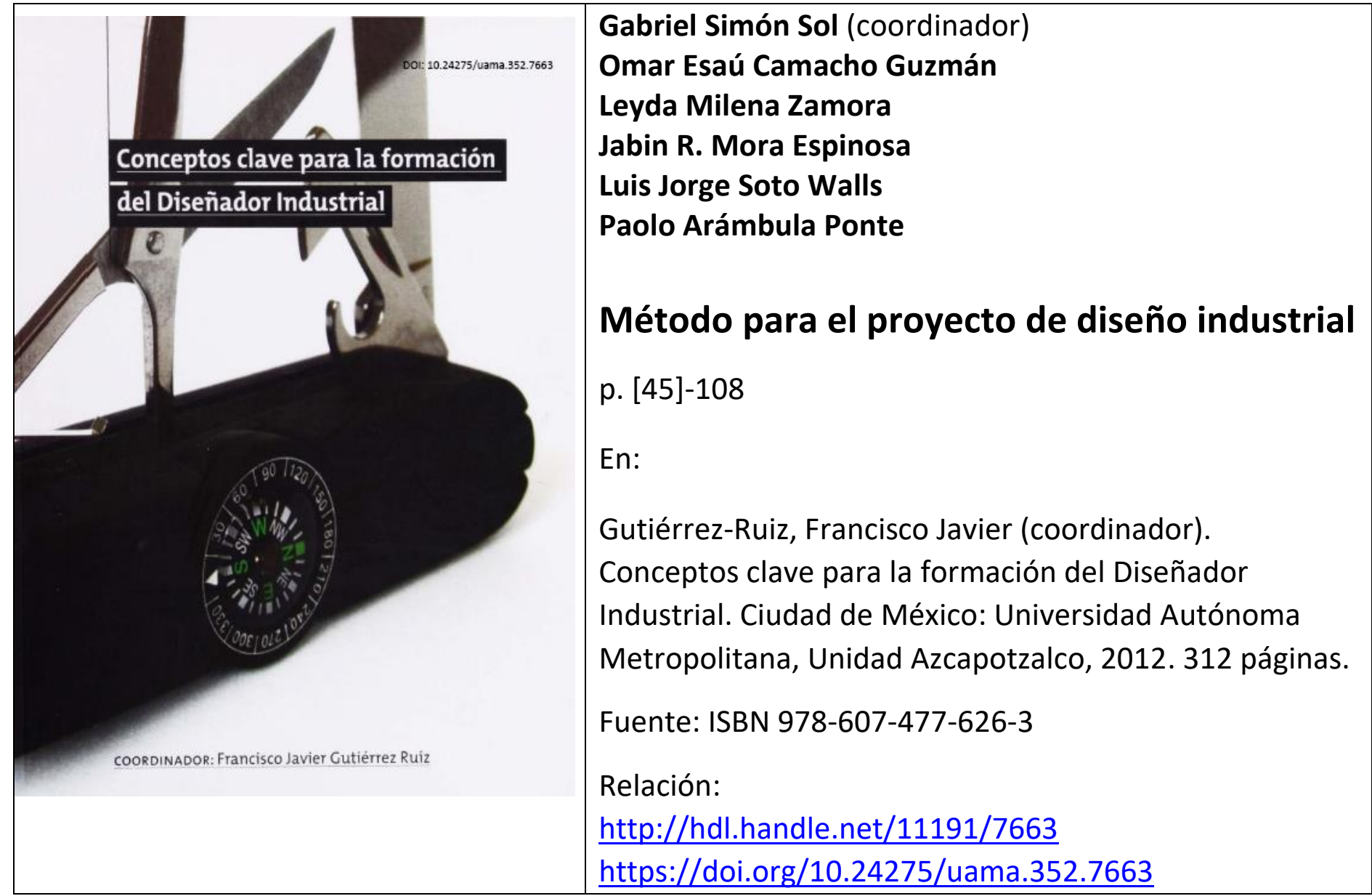

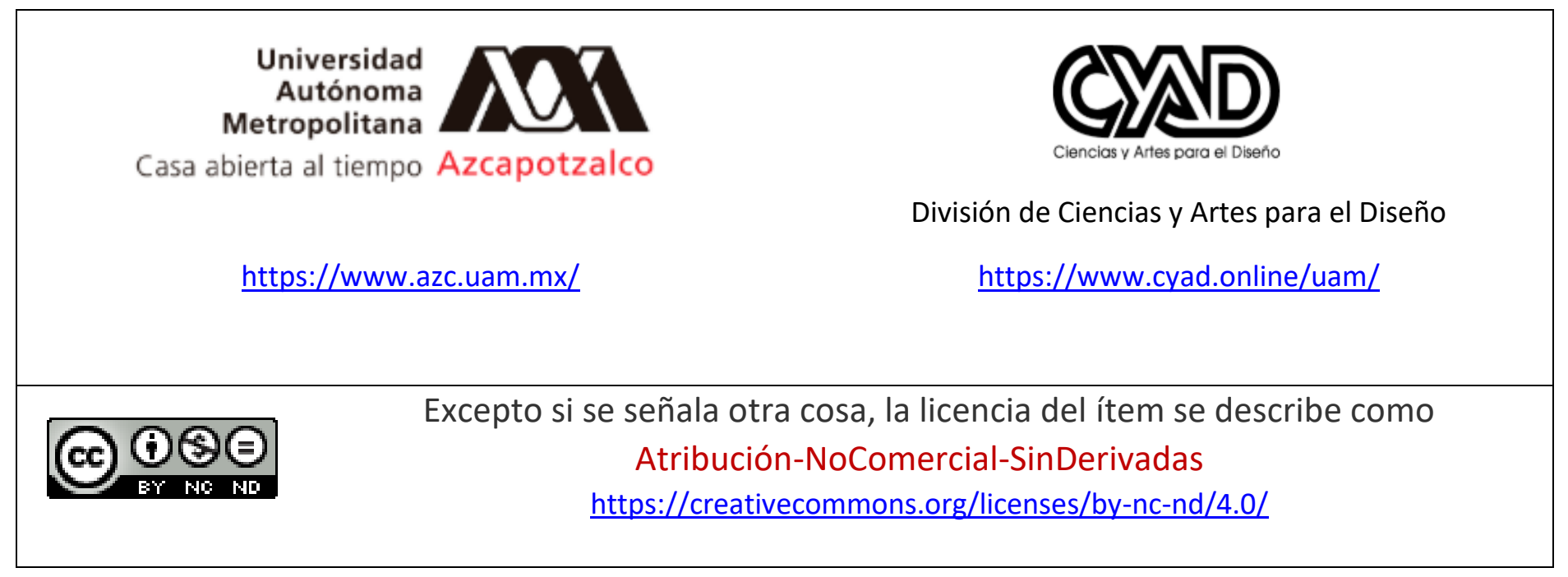

D.R. (C) 2012. Universidad Autónoma Metropolitana. Unidad Azcapotzalco (UAM Azcapotzalco). Se autoriza copiar y redistribuir el material en cualquier medio o formato, siempre y cuando se den los créditos de manera adecuada, no puede hacer uso del material con propósitos comerciales, si remezcla, transforma o crea a partir del material, no podrá distribuir el material modificado. Para cualquier otro uso, se requiere autorización expresa de la UAM Azcapotzalco. 
DOI: 10.24275/uama.7048.7672

- Alternativas de diseño

- Análisis

- Caja negra, caja transparente

- Complejidad

- Concepto de diseño

- Convergencia o sintesis convergente

- Divergencia o análisis divergente de diseño industrial

- Evaluación

- Información e investigación

- Intuición y creatividad

- Lluvia de ideas

o tormenta cerebral

- Método de diseño

- Problema de diseño

- Proceso de diseño

- Propiedad intelectual

- Satisfacción

- Sintesis formal o configurativa

- Técnica, estrategia

y pensamiento estratégico

- Uso, usuario y usabilidad

- Valor 
DESARROLLO DE CONCEPTOS POR:

MTRO. Gabriel Simón Sol (Coordinador)

Profesor del Departamento de Teoría y

Análisis, División CyAD, UAM-Xochimilco

DI. Omar Esaú Camacho Guzmán

Profesor Centro Universitario de Arte,

Arquitectura Diseño del la Universidad

de Guadalajara, Jalisco

MTRA. Leyda Milena Zamora

Profesora de la Escuela de Diseño

del Instituto Nacional de Bellas Artes

DI. Jabin R. Mora Espinosa

Profesor del Departamento de Arte,

Diseño y Arquitectura, de la Universidad

Iberoamericana, Campus Puebla

DR. Luis Jorge Soto Walls

Coordinador General de Desarrollo

Académico, UAM-Azc.

MDI. Paolo Arámbula Ponte

Profesor de la Escuela de Diseño

del Instituto Nacional de Bellas Artes 


\section{Método para el proyecto de diseño industrial}

“...la paradoja de la metodología de la proyectación es que con ella se intenta convertir en rutina lo que nunca puede ser una rutina".

Gui Bonsiepe

En nuestro medio el uso indiscriminado de la palabra metodología ha generado confusiones que entorpecen el entendimiento de dicha disciplina. En primer lugar, constantemente son confundidos método con metodología; esto es, se dice "las metodologías" (en plural), para designar diversos métodos, cuando en realidad existe una sola metodología (en singular) y no varias, entendiendo a ésta como el estudio de los métodos (en plural).

Una confusión parecida suscitan los términos técnica, estrategia, modelo, teoría, procedimiento y fase. Es común oír decir a los diseñadores que "llevaron a cabo un método", cuando, en realidad, lo que hicieron fue aplicar una técnica en cierta fase del proceso de diseño. La técnica del brainstorming o "lluvia de ideas", muy popular en una época, es catalogada frecuentemente como método de diseño, aun en escritos respetables acerca de la metodología de diseño. ${ }^{1}$ Cuando autores como Nigel Cross (1999) hablan sobre "métodos de diseño" lo hacen para describir las técnicas y estrategias más comunes utilizadas en el diseño, en las cuales, obviamente, está el dibujo.

Algo semejante sucede cuando alguien dice que "ha aplicado una metodología", cuando lo que hizo fue seguir los pasos e indicaciones de un método en particular, sin que exista un estudio de la estructura general de los métodos de diseño. Es común, asimismo, la confusión que produce la palabra proceso cuando se relaciona con el método del diseño. A primera vista hablar de método implica siempre un determinado proceso.

\section{7}

$$
\text { (1) }
$$


El proceso como sucesión de actos dirigidos a la consecución de objetivos, habla de una diacronia; es decir, de una cadena de acciones ubicada en el tiempo, sin atender básicamente a la teoría que generan dichas acciones. El proceso habla de qué hacer y cuándo hacerlo, sin importar el para qué hacer ni el por qué hacerlo. El método de diseño, en cambio, tiene que ver con los aspectos que incluyen toda una teoría que tiene la misión de explicar con claridad la razón de cada una de las fases del proceso y detalla, al mismo tiempo, la estructura sincrónica de las mismas.

En ese sentido, el proceso de diseño (o estructura diacrónica del método) nos deja la sensación de una simple receta de cocina. Éstas, bien lo sabemos, son tanto inflexibles como particulares y sus aplicaciones en el diseño son limitadas, poco creativas. El carácter del método no es simplemente descriptivo, sino fundamentalmente normativo de las acciones e implica el uso de estructuras lógicas deductivas y sistematizadas.

La actividad del diseño lleva implícita toda una serie de acciones interrelacionadas, las cuales nos permiten decir que hoy en día existe una complejidad intrínseca en los problemas de diseño. En el pasado esa complejidad relativa permitía encararla tan sólo con la intuición. El aumento en la complejidad de los problemas de diseño, implica que el diseñador debe recurrir a algo más que su intuición. Éste, en principio, realiza una investigación y debe hacer uso de una cantidad caótica de información cada vez mayor que precisa de cierta organización para poder utilizarla.

La variedad de los problemas de diseño crece, tornándose necesario abordarlos desde una perspectiva global que, más que resolver problemas aislados, procure solucionar conjuntos de problemas reunidos en sistemas y subsistemas de mayor alcance. La rapidez con que han proliferado dichas problemáticas hacen pensar cuán difícil, casi imposible, es enfrentarlas empíricamente según la actuación tradicional de los diseñadores, es decir, antes se confiaba más en la experiencia e imaginación de un solo diseñador; mientras que en la actualidad se hace necesaria la colaboración de diversos especialistas bajo un conjunto de directrices previamente acordadas.

La manera tradicional de enfrentar un problema complejo es una operación que actúa sobre una sola concepción del todo (Jones, 1978:26). La ley del "todo o nada" intenta llegar a una solución a través de un golpe único, producto de la chispa intuitiva, dejando de lado la descomposición analíti- 
ca del problema. En tales circunstancias, la solución del problema se da en la cabeza del diseñador, volviéndose prácticamente imposible explicar la mecánica que originó ese golpe de ingenio (Caja negra).

$\mathrm{El}$ diseñador debe predecir el comportamiento futuro, contando únicamente con la información actual que procede de los productos existentes (si es que los hay), ya que el producto se insertará en un futuro "deseable", pero no "asegurable". Esta predicción lo lleva a tener un concepto de diseño que como hipótesis intentará desarrollar en el proyecto (Caja transparente).

El método significa la conducción de estas acciones con cierta planificación; esto es, imponer un orden en las técnicas y estrategias del proceso inventivo, tratando de resolver el conflicto entre el análisis racional y el proceso de creación que procura evitar el azar con la certeza de la razón.

Aunque las características principales del método sean la generalidad de aplicación en más de un caso y la intersubjetividad en la repetición por diversos individuos, no se ha logrado establecer cuáles métodos son los más adecuados a determinados fines. Maldonado sugiere que desde el momento que existen productos con diferente grado de complejidad, también se debería disponer de una variedad de métodos que correspondiera a la complejidad de los satisfactores a desarrollar (Maldonado, 1977:173).

El método es una gramática de acciones basada en el análisis de la conducta organizada con fines determinados. Como conducta planeada, sistemática y controlada, el método viene siendo una selección específica de acciones planificadas. Es una característica particular de un grupo de acciones que tienen un carácter no tanto descriptivo sino normativo. Su justificación proviene más bien de su carácter instrumental. El método, como tal, es una ayuda para determinar la sucesión de acciones (cuando hacer tal o cual cosa), el contenido de las mismas (qué hay que hacer) y para definir los procedimientos específicos que hay que utilizar (cómo hacer, qué técnicas y estrategias emplear). Debe suministrar un marco dentro del cual ha de ajustarse el diseño, permitiendo entresacar la información relevante y la selección de alternativas para la toma de decisiones.

El método nace de la necesidad de crear nexos entre la interpretación de una problemática y la inventiva de un artefacto que le dé solución. El diseño adquiere así una actitud científica que le otorga cierta consistencia moral, al permitirle el rechazo de dogmas, apriorismos o intuiciones prema- 
turas e injustificadas como soluciones definitivas. La articulación del conjunto de factores o variables propias que configuran un todo organizado y funcional, sintetizado en una forma, es, al modo de ver de Llovet, la función y el objetivo, respectivamente, del método de diseño.

La forma de una mercancía está determinada fundamentalmente por el valor de cambio, el valor de signo y valor de uso del objeto que nos obliga, por una parte, a la desarticulación, como descomposición analítica de los contextos de producción, distribución, uso y consumo, y por la otra, a la articulación y sintesis formal de estos presupuestos (Llovet, 1979).

Proponer y realizar objetos y sus elementos constitutivos necesariamente implica reducir el vacío entre el pensamiento y la acción. Esta acción está condicionada por la totalidad de las circunstancias objetivas interactuantes relativas a la época. Tanto la magnitud como la complejidad de usos y sistemas que intervienen en el proceso son determinantes para la concepción de formas. Se hace necesario, pues, desarrollar la capacidad de imaginar y simular los problemas antes de que estos se presenten.

El diseño como profesión es un hecho social, un cuerpo compuesto por hombres y mujeres reunidos mediante ciertas relaciones de organización para realizar determinadas tareas de la sociedad. El método de diseño es, por contraste, una abstracción de estos hechos; por ello existe el peligro de considerarlo como una especie de forma platónica ideal, como si hubiera un camino preciso para encontrar el diseño correcto. Semejante concepción absoluta se encuentra reñida con la historia entera del diseño, con el desenvolvimiento continuo de una multiplicidad de métodos nuevos. El método en el diseño no es una cosa fija, sino un proceso en desarrollo; está formado por diversas operaciones (unas mentales y otras manuales, algunas veces intuitivas y otras más racionales) que constantemente se descubren para llegar a las soluciones de los problemas que plantea la creación de formas útiles y bellas.

Si el diseño ha progresado a buen ritmo en los últimos cien años, eso no se debe tanto a la aportación de sociólogos, filósofos, críticos de la cultura o políticos, sino a la contribución, por cierto más intuitiva que racional, más experimental que científica, de los propios diseñadores. Como dice Llovet: "Los diseñadores no saben exactamente lo que han hecho, pero han hecho algo grande, algo cuyas consecuencias en el campo de la relación interpersonal empieza sólo (ahora) a poder valorarse" (Llovet, 1979:27). 
La teoría requiere de cierta estructuración en torno a los conceptos. La práctica se define como el terreno de la acción, de la ejecución. La metodología construye puentes entre ambas. Atinadamente Bonsiepe reconoce que “...una práctica sin trasfondo teórico degenera rápidamente en un placentero conformismo y ágil oportunismo, mientras una teoría sin raices en la práctica concreta, no va más allá del mero ejercicio verbalista" (Bonsiepe, 1985:14).

Tenemos que construir puentes entre el pensar y el hacer. Enlaces entre un pensar discursivo y un hacer pragmático. Es el verdadero trabajo del diseño y se le ha denominado como un "proceso de conversión" (Bonsiepe, 1978:29).

\section{Gabriel Simón Sol}

\section{Bibliografía}

BONSIEPE, Gui (1985), El diseño de la periferia. Debates y Experiencias. Barcelona: Gustavo Gili.

- (1978), Tecnologia y dependencia, México: Ed. Edicol.

CRoss, Nigel (1999), Métodos de diseño. Estrategias para el diseño de productos, México: Ed. Limusa, Noriega Editores.

Jones, Christopher (1978), Métodos de diseño, Barcelona: Gustavo Gili.

LLOVET, Jordi (1979), Ideología y metodología del diseño. Una introducción crítica a la teoría proyectual, Barcelona: Gustavo Gili.

MALDONADo, Tomás (s/a), Vanguardia y racionalidad. Articulos ensayos y otros artículos: 1946-1974. 


\section{Alternativas de diseño}

\section{Definición Diccionario RAE (DENOTACIÓN)}

Procede del Francés alternative, aquello que se dice o se hace con alternación o que es capaz de alternar con una función igual o semejante. Una alternativa es una opción entre al menos dos cosas (acciones, objetos abstractos o reales) que pueden ser elegidas. Posibilidad de algo que está disponible o solución nueva al alcance. Una alternativa es el elemento de una disyunción lógica, por lo tanto, es cada una de las cosas entre las cuales se elige.

\section{DESARROLLO O CONSTRUCCIÓN DEL CONCEPTO}

La generación de alternativas es el aspecto esencial y central del diseño. El desarrollo de alternativas de diseño se refiere a las múltiples soluciones potenciales que un problema de diseño puede llegar a tener. Esta fase innovadora puede ser considerada como la parte central del proceso proyectual. Sólo se puede hablar de creación cuando la obra es innovadora, cuando ofrece alternativas originales y congruentes. Todos los trabajos preparatorios de análisis y de información deben demostrar ahora su utilidad. Se estudian una serie de ordenaciones experimentales para la configuración de un diseño total. Si consideramos al diseño como un sistema de hipótesis, es decir, como un sistema de conjeturas o anticipaciones que - por principio- no son susceptibles de ser ciertas, pero con las que operamos en espera de contrastarlas con la realidad. Estas conjeturas constituyen la materia prima del trabajo de diseño.
Sorprende que esta fase sea aún la más misteriosa a pesar de todas las técnicas reagrupadas bajo el nombre de sinéctica (Sinectics) para el desarrollo de propuestas alternativas para la solución de problemas proyectuales. Nos referimos a todos aquellos procedimientos tendientes a hallar nuevas soluciones y que, sobre todo, operan con mecanismos de transferencia. Se trata de técnicas heurísticas que prescriben las reglas generales para conseguir metas generales, pero no indica con precisión el camino justo para alcanzar un fin establecido. La cuestión acerca de cómo se le ocurre una idea nueva a una persona puede ser de gran interés para la psicología, pero carece de importancia en el análisis lógico del conocimiento del diseño. Puede verse como un acto misterioso de creatividad o como un proceso lógico de solución de problemas, el propósito es el mismo: hacer propuestas de algo nuevo, que aún no existe. Podemos diferenciar entre el proceso de distinguir una idea nueva y los métodos y resultados de su examen lógico, métodos empleados en las contrastaciones sistemáticas a que debe someterse toda idea nueva antes de que se lleve a cabo. La mayor parte de los diseños tienen una serie de antecedentes de productos o de situaciones ya existentes. Desde que nace, el hombre registra en su mente, consciente o inconscientemente, imágenes y datos significativos que guarda en su memoria, condición necesaria a la reflexión que permite la inferencia, esto es, establecer una serie de posibilidades 0 alternativas diferentes a las ya dadas. Una característica importante de la 
actividad de diseño se centra en la inferencia, en hacer variantes sobre temas establecidos. La creatividad puede verse en muchos casos como un nuevo arreglo o una nueva combinación de elementos existentes. Este reordenamiento creativo es factible debido a que es posible combinar un número relativamente pequeño de elementos o componentes básicos en un gran número de formas diferentes. El método del diagrama morfológico o morfogenético explota este fenómeno y motiva al diseñador a identificar combinaciones novedosas de elementos o componentes, es decir, de morfogramas que ilustran la variedad de alternativas formales que se presenta al diseñador. El número de combinaciones posibles es muy elevado, e incluye no sólo las soluciones convencionales existentes, sino también una amplia gama de variantes que van desde lo más bizarro hasta soluciones completamente novedosas. Importante fase del proceso proyectual donde los conceptos proyectuales son visualizados mediante esbozos, esquemas, premodelos y códices cualitativos y no discursivos. Los criterios deben ser descubiertos e inventivamente propuestos, las hipótesis deben ser el resultado de alternativas nuevas y creadoras.

\section{USOS O ACEPCIONES (ACLARACIONES)}

Alternativa proyectual. Anteproyecto no elaborado en detalle. Posible solución del problema proyectual. Cada una de las soluciones potenciales de un problema de diseño. Hasta hoy día es muy poco lo que se sabe sobre los procedimientos que producen variedad proyectual, es decir, cómo se producen las alternativas proyectuales (bosquejos de diseño). Se puede recurrir a una serie de técnicas como, por ejemplo, la búsqueda de analogías, el "paquete morfológico", el brainstorming. Los conceptos proyectuales son visualizados mediante esbozos, esquemas, premodelos y códices cualitativos no discursivos. Tomar una decisión involucra seleccionar entre esas alternativas. Cada opción implica unas alternativas respecto a los objetivos y al modo de alcanzarlos, así como respecto a quién benefician. Esto significa que el diseño no sólo trata de decisiones iniciales o conceptos creados por los diseñadores, sino también de cómo se llevan a cabo y con qué medios podemos evaluar sus efectos o beneficios.

Alternativas, verificación y selección. Es entendida como la reducción de la variedad. La elección de entre diferentes alternativas es una característica común y muy importante de la actividad de diseño: la fase selectiva (examen de un grupo de alternativas). En esta etapa se selecciona una de estas alternativas para un posterior desarrollo. No podemos reconocer la "mejor" alternativa hasta no haber explorado todas las alternativas viables. Una vez que se ha creado una serie de diseños alternativos, el diseñador enfrenta el problema de seleccionar el mejor. La debilidad fundamental es que el diseñador genera un universo de alternativas desconocidas que resulta demasiado extenso para explorar con el lento proceso del 
pensamiento consciente. La cuestión básica es poder determinar cuándo y cómo es posible juzgar que una alternativa de diseño cumple o no con los requerimientos que se le exigen. Es la fase del proceso proyectual donde se valoran las propuestas presentadas. De todas las variantes posibles ¿cuál será la mejor?, ¿qué tipo de lógica se debe emplear para efectuar la búsqueda?

La elección puede hacerse con base en conjeturas, intuición, experiencia, o tomando una decisión arbitraria. Sin embargo, es mejor si la elección se hace mediante un proceso más lógico, o por lo menos abierto. Hoy dicha evaluación tiene dificultades cientificamente insuperables, aunque se van generando técnicas concretas adaptadas a ciertos tipos de resultados que permiten llegar a algún juicio sobre la rectitud, corrección o valor de la alternativa elegida. Esta fase puede venir acompañada de todo tipo de procesos complicados, por ejemplo de simulaciones que han de proporcionar al diseñador sistemático una imagen de la validez de ésta o aquella solución.

John R. M. Alger y Carl V. Hays (1964) se dedicaron intensivamente a los procedimientos de valoración de las alternativas de proyecto. Siguiendo un elenco de criterios que pueden ser pormenorizados en una lista de control (Checklist) y se refieren, por ejemplo, a la factibilidad funcional, a la coherencia formal, al grado de estandarización, al carácter sistemático, a la complejidad, etcétera, para elegir la más prometedora que en la fase siguiente será reelaborada en sus detalles particulares mínimos.
No sólo el diseñador se sentirá más seguro de su elección, sino que las otras personas implicadas en la toma de decisiones: los clientes, los gerentes y los colegas del equipo de trabajo, pueden participar en la evaluación; permite a cada miembro del equipo de diseño comprobar el grado en que las proposiciones proyectuales son adecuadas. Una evaluación determina el "valor" o "utilidad" global de una propuesta de diseño particular con relación a los objetivos que se supone debe alcanzar. Sin embargo, puede considerarse que cada objetivo tiene diferente "valor" comparado con los otros, es decir, se considera jerárquicamente más importante. Es por eso que para hacer una evaluación es necesario contar con un conjunto de criterios, mismos que deben basarse en los objetivos establecidos al inicio del proceso y que han sido depurados durante el desarrollo del mismo. La lista de objetivos debe contener una amplia variedad de requerimientos de diseño jerarquizados. Este momento del proceso, parte de las propuestas de diseño y termina en una única hipótesis alternativa elegida. La alternativa elegida es como la semilla del árbol futuro.

\section{SINÓNIMOS}

Dilema, disyuntiva, elección, opción.

\section{ANTÓNIMO}

No existe. 


\section{Análisis}

\section{Definición Diccionario RAE (DENOTACIÓN)}

(Del gr. análysis, descomposición). Distinción y separación de las partes de un todo hasta llegar a sus principios, componentes, mecanismos o elementos. El análisis operativo se realiza con base en pasos secuenciales. En la Edad Antigua y parte de la Moderna el análisis tomó sentido de las matemáticas. Presentaba dos características: 1) resolver lo complejo en simple; 2) descender de proposiciones dadas a una proposición evidente, apoyándose en otra proposición que se intenta demostrar y que se acepta como verdadera. Fundamentalmente, se entiende como descomposición de un todo en sus partes, que puede tener una doble vertiente: real (por ejemplo un análisis químico) y lógica o mental, que a su vez se desdobla en análisis de un concepto (notas que lo integran) y análisis de una proposición (elementos que la componen).

\section{DESARROLLO O CONSTRUCCIÓN DEL CONCEPTO}

La noción de análisis implica muchas connotaciones directas o indirectas en el diseño. Adquiere una importante carga de responsabilidad al tener en cuenta adecuadamente todos los datos relevantes para el diseño de un producto. Lo que integra el contexto donde actuará el objeto, que debe ser observado, analizado, cuestionado y registrado. Estos aspectos no son fáciles de describir. El verdadero tema es que estos sistemas de inspección (como el hacer preguntas, escribir informes, etc.) forman parte de la actividad de diseño y no son accesorios. El diseñador deberá incluir en sus competencias una adecuada comprobación de todas las hipótesis que elabora. El pensamiento lógico inherente al diseñador trabaja para los demás y no para sí mismo. Por estas razones la actitud mental es muy importante en los procesos de diagnóstico en general. Hay que entrar en una nueva situación con disposición, pero también con una indulgente predisposición, con la voluntad para comprometerse. De la misma manera en que un diseñador debe aprender a escuchar cuando hace preguntas, también debe aprender a absorber impresiones en el trabajo de análisis.

Por principio diseñar es el procedimiento de analizar, identificar y definir los problemas desde el punto de vista de las relaciones económico-culturales de la sociedad, para así crear y desarrollar productos para su fabricación en serie, atendiendo a su estética, sus lenguajes, significaciones y funcionamiento. El método es el medio de resolución del conflicto que existe entre el análisis racional y el pensamiento creativo. Apunta hacia una consideración sistemática del diseño, tanto desde la perspectiva de la producción como desde la perspectiva del análisis o de la interpretación de los objetos diseñados. El diseñador debe ser totalmente consciente de la "situación problemática"; una gran parte de su trabajo consiste en el análisis del problema, comparable con la responsabilidad que tiene un médico para realizar un diagnóstico acertado con el tratamiento adecuado.

Trabajar en una sociedad que tiende a la industrialización, implica una labor que permita 
no sólo el desarrollo de una sensibilidad perceptiva, sino también una amplia capacidad de análisis. Todos los productos creados por el ser humano en esta sociedad están sujetos a un análisis y un entendimiento que se basan en la naturaleza de la actividad de creación. El diseño es a menudo un campo de compromiso, donde tanto el análisis y la síntesis, como la toma de decisiones y el cálculo de sus consecuencias son sumamente importantes. Este compromiso hace resaltar las posibilidades pedagógicas que el análisis brinda para enseñar a diseñar. Intenta explicar lo que sucede fundamentalmente en las fases previas de prefiguración y figuración; ahí donde aprender a diseñar significa, indudablemente, aprender a conocer.

Con frecuencia, el diseñador industrial antecede a la formulación de alternativas proyectuales un análisis del contexto, para profundizar en el conocimiento de la gama inherente a las posibilidades de acción. El examen del estado del arte proporciona un nivel de partida minimo, por debajo del cual no podría actuar sin el riesgo de fracasar.

\section{USOS O ACEPCIONES (ACLARACIONES)}

La realización de un problema de diseño parece siempre una operación doble: de descomposición analítica del problema que se presente y de articulación y síntesis de esos presupuestos. Una de las técnicas habituales en la solución de un problema de diseño consiste en analizar el conjunto de datos que, de un modo intuitivo y fugaz, se ordenan espontáneamente en el cerebro del diseñador en cuanto se le presenta un problema más o menos inédito. Es común que los diseñadores "vean" en la imaginación la síntesis de la forma antes de descubrir el ensamblaje de cada una de las "partes del problema", es decir, a veces ven primero la solucićn (sintética) de un conjunto de problemas, que las partes de la situación problemática que hay que llegar a reunir y satisfacer en la sintesis de la forma.

Existe un prejuicio común que afirma que el análisis verbal paraliza la creación y comprensión intuitivas. ${ }^{1}$ No es del todo aconsejable que un diseñador se aferre con demasiada insistencia en las soluciones sintéticas intuitivas directas, dejando de lado el análisis, pues podría omitir algunos aspectos incidentes en la forma.

\section{SINÓNIMOS}

Examen, estudio, observación, investigación, razonamiento, exploración, cotejo, diagnóstico, distinción, determinación, diferenciación, separación, descomposición.

\section{ANTÓNIMO}

Sintesis. El análisis se contrapone a la síntesis (composición de lo previamente descompuesto). Pero esta distinción no es excluyente, sino que ambos se complementan en el proceso de diseño.

\footnotetext{
1. No es un prejuicio, es una realidad. El momento en el que el diseñador se detiene para consignar las ideas, en palabras o en bocetos, la calidad propositiva se detiene por momentos. La velocidad de la mente es tal que si no se consigna lo que ya se tiene, el proceso cíclico proyectar-consignar nunca terminaría (Comentario de la dictaminación).
} 


\section{EJEMPLOS}

Análisis de la sensibilidad. Persigue un conocimiento más profundo de los mecanismos internos del sistema, identificación de los parámetros críticos del diseño distinguibles de los menos críticos, una indicación sobre si algunas restricciones deben aumentarse o disminuirse, una idea más cuantitativa sobre el comportamiento general que cabe esperar del sistema.

Análisis de la compatibilidad. Un objeto de diseño puede concebirse como un sistema compuesto de una combinación de piezas de un orden menor de complejidad. En el caso de un sistema complejo, éstos se denominan subsistemas. Proyectar un sistema en su totalidad exige examinar, por lo menos, los elementos de primer orden que lo componen. Para que la acción conjunta o interacción tengan lugar satisfactoriamente, es preciso que los objetos individuales sean compatibles con los demás miembros del sistema.

Análisis de la estabilidad. Su propósito es explorar el funcionamiento de un sistema de manera que se logre tener la seguridad de que éste, en su conjunto, no es inherentemente inestable, determinar las partes que pueden ser inestables en el espacio de los parámetros del proyecto, evaluar los riesgos y consecuencias de las perturbaciones ambientales que pueden ser suficientes para causar malos funcionamientos o aun fallas catastróficas y aportar más pruebas en pro y en contra de la elección final de un concepto de diseño en particular.

Análisis de las necesidades. Ante la solicitud de diseño, lo que tenemos es un despliegue embrionario de las necesidades. Por embrionario entendemos que la muestra representa una opinión basada principalmente en observaciones casuales, pero no confirmadas por evidencias organizadas. Tales opiniones son valiosas como puntos de partida cuando provienen de personas que han tenido la oportunidad y poseen la capacidad de hacer observaciones y de apoyarlas con juicios bien fundamentados. La enunciación rudimentaria sugiere una situación problemática que puede, por ejemplo, concebirse como una pretendida necesidad, expuesta en forma primitiva. Es preciso evitar los peligros de asignar a los usuarios las necesidades que en nuestra opinión tienen, pues corremos el riesgo de prejuzgar lo que creemos posible. Por otra parte, lo que los compradores afirman que es deseable puede diferir de forma sorprendente de lo que necesitan los usuarios. Las necesidades que deseamos determinar son las efectivas que existirán cuando el producto esté listo para salir al mercado, muchos meses después. Tenemos muchas preguntas qué plantear: deseamos detallar las necesidades con precisión, en función de las maneras en las cuales el usuario consumirá el producto. Queremos saber quiénes serán los consumidores y en qué categorias se les puede clasificar.

Análisis de las funciones. Ofrece un medio para considerar las funciones esenciales y el nivel en el que la situación problemática debe abordarse. Las funciones son aquellas que al diseñar debe satisfacer el objeto, producto o sistema, independientemente de los componentes físicos que pudieran utilizarse. El nivel del problema se decide 
estableciendo "límites" alrededor de un conjunto coherente de funciones. Habrá que concentrase en lo que el nuevo diseño debe lograr y no cómo se va a lograr. Se deberá preguntar cuáles son las entradas y salidas requeridas: ¿de dónde proceden las entradas? ¿Cuáles deben ser las salidas? ¿Cuáles son las transformaciones necesarias para convertir las entradas en salidas? La conversión de entradas en salidas es una tarea compleja por lo que es necesario descomponerla en actividades secundarias.

Análisis de las actividades. Éste continúa el esfuerzo iniciado en el análisis de las necesidades y de las funciones para elaborar la exposición total. La actividad del ser en el transcurso del tiempo se compone de una serie de acciones situadas, en los casos más simples, unas después de otras en el tiempo, más o menos separadas y separables en nuestra conciencia, por pausas o tiempos muertos. Por lo general, cada acción puede ser descompuesta en una secuencia de elementos más simples. Estas acciones pueden ser individuales o colectivas, acciones directas o indirectas.

La meta del análisis de la actividad es determinar los límites y las condiciones limitativas que se aplicarán a cualquier sistema antes de poderlo considerar como una solución posible. El análisis de la actividad prescribe un modo general de ataque basado en las entradas (inputs) y de las salidas (outputs) exigidas a un sistema cuya forma aún se desconoce. Este modo de ataque constituye la estrategia general. El problema específico del análisis de la actividad es la realización práctica de la estrategia con las tácticas adecuadas, es decir, con un plan detallado que se adapta a la situación problemática.

Las salidas deseadas del sistema se derivan de las necesidades efectivas del consumidor. El lenguaje de las salidas debe ser más preciso que el de las necesidades y deberá reflejar lo que el sistema hace o proporciona en respuesta a las demandas de producción.

Se deducen las salidas indeseadas del sistema. Parece casi inevitable que haya salidas indeseables que acompañan a la producción deseada.

Las entradas que el sistema transforma en salidas se deducen. Podemos clasificar las entradas dentro de cinco categorías: físicas (energía, materiales y mecanismos), humanas (esfuerzo, control y confort), informativas (señales, datos e instrumentos), económicas (costos de operación, mantenimiento y depreciación) y ambientales (clima, humedad y viento).

Se determinan las restricciones que se aplicarán tanto a las salidas como a las entradas. En la mayoría de los casos, estos factores adoptan la forma de especificaciones, límites, tolerancias y otras definiciones de características y cualidades aceptables y limitativas.

Las restricciones sobre el sistema en sí se consideran a la par de cualquier parámetro del proyecto que sean evidentes (dimensiones, peso, velocidad). Muchos de estos atributos serán los parámetros para el proyecto.

Se establecen las medidas apropiadas del valor para las entradas y salidas y para los parámetros del proyecto. Merced a ello estaremos en capacidad de cuantificar el análisis. En algunos casos tal asignación seguirá siendo intangible. 
Los criterios de juicio para medir la excelencia de las alternativas propuestas se elaboran a partir de las relaciones apropiadas entre las variables, o sea las entradas, las salidas y los parámetros del proyecto. Alguno de los criterios más útiles en relación con variables que puedan medirse, estarán de manera cuantificada.

Análisis del valor de uso. Consiste en agrupar, clasificar y jerarquizar los servicios que se esperan de un producto mediante análisis comparativos entre los productos existentes en el mercado que llegarían a competir con nuestro diseño. Un producto puede ser considerado como una suma de funciones diversas, pero también puede ser considerado como una suma de funciones que responden a las expectativas del usuario. Los estudios previos de motivación realizados con los consumidores potenciales no siempre concuerdan con los estudios efectuados después de la utilización del producto por el consumidor. Es necesario un análisis crítico de los productos de consumo. Este análisis debe hacer referencia al tiempo empleado en la manipulación y al mantenimiento de los productos, a su adaptación al uso y a los datos ergonómicos sobre su coeficiente de fiabilidad o de seguridad. La técnica consiste en establecer correlaciones entre los tipos de productos y los tipos de utilización, y procede por etapas:

- Definiciones de los diferentes tipos de utilización.

- Identificación de las características técnicas de los diferentes productos para agruparlos en categorías.
- Clasificación de las funciones.

- Dimensiones de las funciones elementales.

- Ponderación del valor atribuido a cada función según los diferentes tipos de utilización.

Análisis de la secuencia de uso. A grandes rasgos esta técnica consiste en que una persona (o grupo de distintos usuarios) lleve a cabo todas las acciones implícitas en el uso de un objeto en un contexto determinado, mientras que un observador adiestrado presta atención a aquellos aspectos relevantes. La secuencia de uso se plasma en un diagrama que muestre cada una de las acciones llevadas a cabo por el (los) usuario(s), señalando aquellos aspectos llamados áreas criticas, que sean considerados como indeseables o que representen un obstáculo para el diseño. El análisis empieza antes del uso estricto del objeto (actividades previas) se desarrolla con la actividad central (la función principal) y termina después de esta actividad con actos ulteriores (actividades posteriores a la función). No debe descartarse la observación de acciones no contempladas (actividades emergentes) que completan la secuencia de uso. Si bien en ocasiones es fácil imaginar una secuencia de uso, muchos datos relevantes surgen de la observación, por lo que se recomienda la representación directa de la actividad, con un usuario real, en tiempo real y en condiciones lo más apegadas a la realidad. Resulta de gran ayuda grabar un video o al menos tomar fotografías para poder realizar un análisis detallado.

Análisis del valor (costos). El objetivo del análisis del valor (value analysis) es el de reducir los costos de los productos y servicios sin reducir 
sus prestaciones. En otras palabras, el análisis del valor trata de mejorar el rendimiento económico mediante la reducción de costos cuando éstos no responden a una necesidad real. La técnica da prioridad a la función y a la economía intentando no alterar la apariencia y prestaciones del producto.

\section{Caja negra, caja transparente}

\section{DEFINICIÓN Diccionario RAE (DENOTACIÓN)} Caja (Del lat. Capsa.) Depósito, hueco o espacio dispuesto para que se introduzca una cosa o cosas.

\section{DESARROLLO O CONSTRUCCIÓN DEL CONCEPTO} Caja negra u oscura. Término utilizado en cibernética para designar aquellos mecanismos ocultos o no conocidos mediante los cuales determinadas entradas son transformadas en salidas del sistema. Desde un punto de vista creativo, el diseñador tiende a ser una "caja negra" dentro de la cual ocurre un misterioso salto creativo: la comprensión repentina del problema y su solución inmediata.

Caja transparente o caja de cristal. La necesidad de un método ha dado lugar a un lenguaje ya común en el medio del diseño, en particular los conceptos "caja negra" y "caja transparente". Los llamados métodos de "caja transparente", son aquellos donde el proceso puede ser observado, analizado y verbalizado, por lo que podemos saber qué pensaba el diseñador y qué secuencia siguió para obtener un resultado.

\section{USOS O ACEPCIONES (ACLARACIONES)}

Una importante minoria de teóricos del diseño, principalmente Osborn (1960) y Broadbent (1976) sugieren que la parte más valiosa del proceso de diseño se produce en la mente del diseñador $\mathrm{y}$, parcialmente, fuera de su control consciente. A pesar de su propuesta "irracional", el punto de vista de la caja negra puede expresarse con claridad mediante términos psicológicos o cibernéticos: el diseñador humano, al igual que otros animales, es capaz de dar respuestas u outputs en los que confia y que con frecuencia tienen éxito sin que pueda explicarse. Muchas de las acciones humanas únicamente encuentran explicación si se supone que están gobernadas en gran medida por un sistema nervioso en el que no interviene el pensamiento consciente. Si consideramos la existencia humana como una caja negra, parece lógico suponer que la desaparición de inhibiciones en el output final incrementará al menos la cantidad de los outputs cuando no su calidad.

La "caja negra", según Jones (1978), se basa en ciertas consideraciones:

- La producción de un diseñador está dominada por las entradas de información (inputs) más recientes procedentes del problema, y también por otras que provienen de cuestiones y experiencias anteriores.

- Esta producción puede ser acelerada y convertida en más aleatoria mediante la decisión de relajar, durante cierto periodo, las inhibiciones sociales.

- A lo largo de una extensa y aparente infructuosa búsqueda de la solución, puede percibir repentinamente una nueva manera de 
estructurar el problema de modo que se resuelvan los conflictos; esta agradable sensación se suele denominar "visión repentina".

- El control inteligente sobre la manera de introducir la estructura de un problema dentro de la caja negra, tiende a incrementar las oportunidades de obtención de outputs adecuados al problema de diseño.

La mayoría de los métodos de diseño están interesados, en mayor o menor grado, en la exteriorización del pensamiento de diseño y, por tanto, basados en presupuestos racionales, más que en místicos. Se supone que el proceso de diseño es totalmente explicable, incluso aunque el diseñador sea incapaz de dar razones convincentes para todas las decisiones que toma. La imagen de un diseñador racional o sistemático se parece mucho a una computadora; una persona opera exclusivamente con la información que recibe, y lleva a cabo su labor mediante una secuencia planificada de etapas y ciclos analíticos, sintéticos y evaluativos hasta reconocer la mejor de todas las posibles soluciones.

Las características comunes a los métodos de "caja transparente" son las siguientes:

- Los objetivos, variables y criterios de evaluación son claramente fijados de antemano.

- El análisis del problema se completa, o al menos se intenta completar, antes de iniciar la búsqueda de soluciones.

- La evaluación es fundamentalmente lingüística, verbal y lógica (con oposición a lo experimental).
- Las estrategias se establecen de antemano y generalmente funcionan de manera secuencial, aunque puede incluir operaciones paralelas, condicionales y retroalimentadores.

\section{SiNÓNIMOS}

Arca, cajón, cofre, urna, recipiente, envase, receptáculo.

\section{Antónimos}

De caja negra u obscura: caja transparente o traslúcida.

De caja transparente o traslúcida: caja negra u obscura.

\section{EJEMPLOS}

Se puede afirmar que tanto el método de caja negra como el de caja transparente tienen como resultado ampliar el espacio de búsqueda de la solución al problema de diseño. Mediante una sucesión de momentos, tanto de caja transparente como de caja negra, que a su vez se podrían definir como aquellos en que el comportamiento es conceptualizable y momentos en que se torna radicalmente imaginativo.

\section{Complejidad}

\section{Definición Diccionario RAE (DENOTACIÓN)}

(Del lat. complexus). Cualidad de aquello que se compone de elementos diversos, producto de la unión de dos o más cosas. Un sistema complejo es un sistema compuesto por varias partes interconectadas o entrelazadas cuyos vínculos 
contienen información adicional y oculta al observador. Como resultado de estas interacciones entre los elementos del sistema, surgen propiedades nuevas que no pueden explicarse a partir de las propiedades de los elementos aislados. Para describir un sistema complejo hace falta no sólo conocer el funcionamiento de las partes sino conocer cómo se relacionan entre sí.

\section{DESARROLLO O CONSTRUCCIÓN DEL CONCEPTO}

El diseño industrial es una disciplina compleja vista desde diferentes perspectivas. Es compleja en el sentido de desarrollar-materializar objetos que se componen generalmente por la unión de dos o más elementos; es compleja cuando el punto de partida para el análisis de esta disciplina es el proceso que siguen los diseñadores industriales al desarrollar su actividad; es compleja si se analizan los métodos utilizados y sus fases para el desarrollo de los proyectos de diseño industrial.

La magnitud de la complejidad es la métrica propia de lo que caracteriza al universo de los objetos, entendidos como sistemas que están articulados por relaciones entre sus elementos. La noción de complejidad mide una propiedad inherente a todo un universo combinatorio y comporta tantos aspectos o dimensiones, como nuevos puntos de vista que descubre el individuo sobre el mundo exterior. El diseño es la fase relativamente compleja y minuciosa del proceso productivo que implica un empeño constante por comprender las circunstancias de una realidad también compleja y cambiante.

\section{USOS O ACEPCIONES (ACLARACIONES)}

Entender de manera consciente que en todo método del proyecto de diseño existe la complejidad y que está de manera intrínseca en toda actividad humana, generará en el diseñador industrial un mejor entendimiento de su profesión y permitirá enfrentar los posibles problemas que se le presenten de manera abierta, con una postura dialéctica entre lo racional y lo intuitivo.

Según Abraham Moles "hay dos dimensiones ligadas a la descripción de un sistema u organismo unitario: la complejidad estructural y la complejidad funcional (...) Complejidad estructural y complejidad funcional son, pues, las dimensiones esenciales del mundo de los objetos o de los organismos, y permiten trazar un mapa del mundo de los objetos" (Moles, 1975:32-33).

Complejidad estructural. Composición de elementos diversos cuyo número de conexiones estructurales hacen complicado un objeto. Se relaciona con la variedad del repertorio de elementos y de sus combinaciones.

Complejidad funcional. Está determinada por el número de operaciones y relaciones posibles entre ellas que un producto puede llegar a tener; así como está relacionada con las necesidades de los individuos, miembros del mercado. Es una dimensión estadística de los usos, un repertorio de funciones, una variedad de los actos elementales que el hombre puede combinar en la utilización de un objeto.

Un diseñador deberá entender que el proceso de diseño industrial en todo momento tiene un grado de complejidad, pero eso no implica 
que el resultado que se obtiene al diseñar deba tener la cualidad de complejo.

\section{SiNóNIMOS}

Complicación, confusión, enredo, laberinto, obscuridad, problema, diversidad, variedad, composición, multiplicidad, pluralidad.

Dentro de la teoría de la complejidad podemos encontrar los siguientes conceptos ligados a ésta: flexibilidad, equilibrio dinámico, auto organización, caos, atractores, bifurcación, dialéctica, retroalimentación, no linealidad y fractalidad.

\section{ANTÓNIMOS}

Sencillez, facilidad, simplicidad, claridad.

\section{EJEMPLOS}

Una manera de poder entender la complejidad es haciendo uso de una de las características principales que debe tener cualquier diseñador que se precie de serlo: la observación. En la observación de la vida cotidiana se puede apreciar que no existe división alguna de factores que influyan en la toma de decisiones; si bien, se puede considerar que analizar (separar) los factores que impactan en el proyecto de diseño nos permite tener claridad para diseñar, creer que éstos se encuentran separados en la vida cotidiana, representa un grave error, ya que esto sólo puede existir en abstracto.

En la complejidad desde el punto de vista de la teoría de ésta, a diferencia de la definición dada en el Diccionario de la Real Academia Española, lo importante no es cuántos factores están en juego sino cómo se relacionan entre sí para formar un todo. Lo importante cuando se analizan los factores que impactan en el proceso de diseño es la interacción que se da entre éstos y no la cantidad y el entendimiento individual de los mismos.

\section{Concepto de diseño}

\section{Definición Diccionario RAE (DENOTACIÓN)}

Término que adquiere sentido por la interrelación de las dos palabras.

Concepto: (Del lat. conceptus) idea que concibe o forma el entendimiento. Construcción mental que nace como una idea abstracta. Pensamiento expresado con el lenguaje. Determinar algo en la mente después de examinadas las circunstancias.

Diseño: (Del ita. disegno) traza o delineación de una figura. Concepción original de un objeto u obra destinados a la producción y también puede referirse a un proyecto o plan.

Construir conceptos es la forma más sencilla de pensar, en oposición al juicio y al raciocinio, que son productos compuestos del pensamiento. Reproduce los caracteres esenciales de las cosas con instrumentos o símbolos que permitan describir, clasificar, organizar y prever los fenómenos. El concepto es el reflejo de los fenómenos del mundo objetivo en la conciencia del hombre con sus propiedades generales y esenciales. Es un modo de entender o imaginar en el pensamiento un nuevo producto antes de que éste exista. Noción configurativa del producto en abstracto. 


\section{DESARROLLO O CONSTRUCCIÓN DEL CONCEPTO}

Para el diseño industrial el concepto de diseño puede expresarse por medio de una declaración verbal o preferentemente escrita, que condensa de manera abstracta y sintética un arreglo de cómo el objeto puede llegar a ser. Por lo tanto, el concepto de diseño es parte del proceso proyectual por el cual se especifican las necesidades a satisfacer del usuario o usuarios objetivos, así como las funciones y semiótica del producto, que a su vez como resultado de este procedimiento se desprende el concepto del producto en el cual se asignan las cualidades formales, las funciones a desempeñar y el contexto en el que será utilizado.

Así, el diseño es resultado de la inteligencia y sensibilidad humanas que determinan los objetos mediante una actitud mental, un proceso de conceptualización, que los crea y los mejora y cuya actividad no surge espontánea sino es producto de una ordenación de sucesos de la vida y sus interrelaciones.

Como representación simbólica, normalmente por medio de lenguajes de una idea abstracta y general, el concepto de diseño determina la forma (no detallada) del elemento, producto, sistema o servicio que se diseña, después de examinar las circunstancias que originaron el problema. Sus notas esenciales son la "comprensión" y la "extensión". La comprensión de un concepto alude a las notas contenidas en el mismo y que le corresponden esencialmente (connotación) y la extensión de un concepto alude al conjunto de objetos a los que puede atribuirse (denotación).

Entonces, el concepto de diseño, se entiende, en general, como el proceso previo de configuración mental en la búsqueda de una solución, que permite plasmar el pensamiento a través de esbozos, dibujos, bocetos y esquemas trazados en diferentes soportes. Asimismo, permite determinar las cualidades formales, operativas, funcionales, expresivas y de significado de un objeto y los atributos que se le otorgan. Sus características o caracteres distintivos como criterios de diseño, forman lo que se llama el "campo de datos" que le da cuerpo a las hipótesis del diseño. Tal vez lo más importante que aporta el concepto de diseño, es que se lleva a cabo a partir de una forma renovada de ver el mundo y una nueva manera de interpretar las necesidades que presenta. Es producto de una reflexión sobre el entorno físico y cultural, así como del grupo de usuarios a los que va dirigido. Hace una reinterpretación de las necesidades, los deseos, los gustos y los anhelos de las personas.

\section{USOS O ACEPCIONES (ACLARACIONES)}

Suele utilizarse en el contexto del diseño industrial, diseño gráfico, de las artes, la ingeniería, la arquitectura y diversas disciplinas creativas.

\section{SINÓNIMOS}

Noción, opinión, juicio, concepción, conocimiento, percepción, agudeza, ingenio, significación, sensación, sentencia, pensamiento, idea, bosquejo, esbozo, delineación, esquema, proyecto, creación, invención, perfilar, descripción.

\section{ANTÓNIMO}

No existe. 


\section{EJEMPLOS}

El término de concepto de diseño, aparece frecuentemente unido a otros dos: proceso de diseño y creatividad. Generar un concepto de diseño requiere de un proceso complejo que abarca una serie de etapas en las que se analiza, sugiere, desecha, retoma, corrige, afina detalles, se prueba, se evalúa y se decide. Las decisiones reflejadas en un concepto de diseño, integran las consideraciones funcionales, operativas formales y de mercado del producto o servicio a materializar.

La conceptualización, como la acción de producir conceptos, es una perspectiva abstracta y simplificada del conocimiento que se tiene del "mundo", y que por cualquier razón se quiere interpretar. Esta representación es nuestro conocimiento del "mundo", en el cual cada concepto es expresado en términos de relaciones verbales, simbólicas, con otros conceptos y con sus ejemplos "del mundo real" (relaciones de atributo, etc., no necesariamente jerárquicas), y también con relaciones jerárquicas (la categorización, o asignación del objeto a una o más categorías) múltiples (el objeto pertenece a diversas jerarquías simultáneamente, lo que quita el aspecto total o exclusivo de jerarquía a la conceptualización). Conceptualizar, por lo tanto, puede ser considerado como "el desarrollo o construcción de ideas abstractas a partir de la experiencia: nuestra comprensión consciente (no necesariamente verdadera) del mundo".

\section{Convergencia o sintesis convergente}

\section{Definición Diccionario RAE (DENOTACIÓN)}

Unión de dos o más cosas, ideas y tendencias sociales, políticas, culturales o económicas que confluyen en un mismo punto. Con frecuencia se da este nombre al lugar u punto donde ocurre dicha reunión.

Convergencia adaptativa o evolutiva: proceso adaptativo según el cual los organismos que pertenecen a grupos sistemáticos diferentes y que se desenvuelven en un mismo medio desarrollan o adquieren caracteres (funciones y órganos) parecidos que dan lugar a analogías.

Convergencia cultural: proceso de dinámica cultural en el cual dos o más culturas contienen instituciones similares.

\section{DESARROLLO O CONSTRUCCIÓN DEL CONCEPTO} Proceso en el cual evolucionan las altemativas posibles hacia una solución formal definitiva. Tipo de pensamiento que requiere de una sola respuesta correcta a una pregunta o problema planteado.

Según el esquema del proceso de diseño de Christopher Jones (1978), la convergencia es la tercera fase posterior a la definición del problema, a la identificación de variables y al acuerdo de los objetivos. El objetivo del diseñador estriba en alcanzar una única alternativa entre muchas posibles, mediante una reducción progresiva de las incertidumbres secundarias hasta llegar a una solución formal. La convergencia es la reducción de una gama de opciones a un único diseño sin necesidad de retrocesos. 
Esta etapa se caracteriza por:

- La persistencia y la inflexibilidad de pensamiento y método es una virtud;

- La dificultad de la convergencia estriba en la claridad de los subproblemas críticos, es decir, que sean insolubles a menos de que se cambie una primera decisión;

- Aunque los modelos matemáticos y las analogías abstractas se adecuan a las primeras etapas de la convergencia, los modelos utilizados para representar la gama de alternativas que permanecerán, son menos abstractos y más detallados durante las últimas etapas;

- Una elección entre dos estrategias fundamentalmente opuestas para la convergencia pueden ser la convencional out-in (de afuera hacia adentro) o la in-out (de adentro hacia fuera). Por lo general, un diseñador experto trabaja teniendo ambos fines. El in-out supone soluciones aisladas para subproblemas antes de emitir pensamientos para su combinación.

\section{USOS O ACEPCIONES (ACLARACIONES)}

Pensamiento convergente. Requiere de una sola respuesta correcta a una pregunta o problema planteado (comparar con el pensamiento divergente). Al observar el entorno social como un juego de intereses en conflicto y fuerzas de poder, permite al diseñador ampliar su enfoque hacia la búsqueda de convergencias, suma de recursos y distribución de beneficios, en el juego de hacer diseño en un entorno determinado. La forma como mediadora entre el hombre y su contexto es el lugar de encuentro entre exigencias, requerimientos y limitaciones de muy diversos campos que en ella convergen. Adentrándose en esa problemática plural, captada en toda su complejidad, el diseñador proyecta, entonces, una forma a la vez congruente y armoniosa que asume toda esa globalidad.

\section{SINÓNIMOS}

Coincidencia, concurrencia, confluencia, juntura, unión.

\section{ANTÓNIMOS}

Bifurcación, desacuerdo, diferencia, disentimiento, divergencia, separación.

\section{Divergencia o análisis divergente}

\author{
Definición Diccionario RAE (DENOTACIÓN) \\ Divergencia [diße'yen $\theta j a$ ]. Disparidad en el pa- \\ recer o pensamiento. Separación de dos o más \\ elementos. Falta de coincidencia entre las ideas \\ y tendencias sociales, culturales o económicas \\ de varias personas o grupos. Cualidad de algo \\ que no tiene convergencia.
}

\section{DESARROLLO O CONSTRUCCIÓN DEL CONCEPTO}

Según Jones es una de las etapas esenciales del proceso de diseño. Es el acto de ampliar los límites de la situación de diseño y la obtención de un espacio de investigación lo suficientemente amplio y fructífero para la búsqueda de una solución. Las principales caracteristicas de la investigación divergente son: 
- Los objetivos son inestables y experimentales.

- El límite del problema es inestable e indefinido.

- La evaluación se aplaza.

- Las órdenes del promotor se consideran puntos de partida para la investigación.

- El objetivo del diseñador es incrementar deliberadamente la diversidad de opciones de solución.

- Analizar la sensibilidad de los promotores, usuarios, mercados, productores, etc., y la exploración de las direcciones de tales sensibilidades.

La investigación divergente es un análisis de la estabilidad o inestabilidad de todo lo que está conectado con el problema, un intento por descubrir lo que en la jerarquía de valores de la comunidad (y en la mente de aquellos que tomarán las decisiones críticas), es susceptible de cambio y lo que se puede considerar como puntos fijos de referencia. Es tan probable que se descubran los puntos estables e inestables a nivel de productos y componentes como a los más altos niveles de metas colectivas y juicios personales de valor, que no se puede esperar que surja una imagen en esta etapa. Evitar, en la medida de lo posible, la imposición de modelos prematuros en sus descubrimientos, postergando las decisiones hasta la próxima etapa. Unl error frecuente de esta etapa es hacer preguntas equivocadas.

El objetivo de la investigación divergente es la destrucción del orden inicial mientras se identifican las características de la situación de diseño que permitan un cambio valorable y factible. Es el tipo de pensamiento que se requiere para producir múltiples interpretaciones a una misma pregunta o problema.

\section{USOS O ACEPCIONES (ACLARACIONES)}

Pensamiento divergente. Es el tipo de pensamiento que se requiere para producir múltiples respuestas a una misma pregunta o problema (comparar con pensamiento convergente).

\section{SINÓNIMOS}

Bifurcación, desacuerdo, desajuste, desemejanza, diferencia, disconformidad, disentimiento, disparidad, discrepancia, oposición, separación.

\section{ANTÓNIMOS \\ Convergencia, coincidencia.}

\section{Evaluación}

\section{Definición Diccionario RAE (DENOTACIÓN)}

El concepto de evaluación se refiere a la acción y efecto de evaluar, un verbo cuya etimología se remonta al francés évaluer que significa señalar, estimar, apreciar o calcular el valor de algo.

Proceso que tiene como finalidad determinar el grado de eficacia y eficiencia con que han sido empleados los recursos destinados a alcanzar los objetivos previstos, posibilitando la determinación de las desviaciones y la adopción de medidas correctivas que garanticen el cumplimiento adecuado de las metas presupuestadas.

\section{DESARROLLO O CONSTRUCCIÓN DEL CONCEPTO} La evaluación es un proceso continuo de reunión 
e interpretación de información para valorar la toma de decisiones en el diseño de un producto. Se aplica antes de realizar las alternativas de diseño, durante su búsqueda y después de las actividades de formalización del proyecto. Antes de haber empezado los primeros bosquejos, antes de comprometerse con una alternativa, antes de completar los dibujos técnicos del proyecto, antes de que comience su producción, antes de que el producto haya salido al mercado, antes de su instalación y antes de que se use.

El proceso de evaluación no está sujeto al azar, sino que se encuentra dirigido hacia una meta especifica y su finalidad es encontrar respuesta sobre la manera de mejorar la forma de un producto.

La elección entre diferentes alternativas es una característica de la actividad de diseño. Una vez que se han creado una serie de alternativas de diseño podemos someter las soluciones a prueba en lo abstracto, confrontándolas con el espectro de requisitos exigidos por la situación problemática, y de esta manera llegar a una evaluación. Al hacerlo, así podemos someter las diversas alternativas de diseño usando parámetros de funcionamiento, algunos objetivos y otros subjetivos, algunos cuantitativos y otros cualitativos.

La elección puede hacerse con base en conjeturas, intuición, experiencia o tomando una decisión arbitraria. Sin embargo, es mejor si la elección se hace mediante un procedimiento más lógico, o por lo menos abierto.

Dependiendo de la etapa del proceso, la evaluación contempla por lo menos cuatro maneras de ser llevada a cabo:
- Recolección y evaluación de la experiencia y apreciaciones críticas disponibles.

- Simulación, por medio de cualquier modelo disponible, mediante el uso de análogos, programas de cómputo y experimentación.

- Predicción lógica, por medio de mapas de interacción y redes que "diseñan" como cuadros de pertinencia, matrices morfológicas, etc.

- Construcción de prototipos, producción de pequeñas series iniciales, antes de emprender la fabricación a gran escala.

Con las evaluaciones decidimos cuál de las alternativas de diseño es la solución aceptable, tomando en consideración la posibilidad de que cualquiera de las alternativas en particular puede arrojar resultados positivos aplicables a la alternativa seleccionada.

\section{USOS O ACEPCIONES (ACLARACIONES)}

La idea de evaluar las propuestas de nuevos proyectos y establecer sus posibles efectos sociales y ecológicos, con el fin de descartar aquellos que sean perjudiciales, está teniendo amplia aceptación en diversos países. Aunque es posible desarrollar diferentes técnicas de evaluación, hay una cantidad de problemas obvios en su realización y utilización.

Existen diseñadores que piensan que el diseño tiene que demostrar su valor con mediciones concretas y, por otro lado, están los que sienten que no tienen que justificar nada porque el diseño es una cuestión de convencimiento y no de razonamiento. En efecto, hay momentos específicos o casos particulares en los que necesitamos 
demostrar algo tangible y habrá casos en los que no hace falta hacerlo. Parte de la dificultad es la de aprehender exactamente el significado de lo tangible, desde un punto de vista formal, y la otra dificultad radica en encajar los intangibles en unos sistemas de medición.

\section{SinÓNIMOS}

Valor, valorar, eficacia, eficiencia, tasar, justipreciar, ajustar, calcular, tantear, apreciar, estimar, juzgar.

\section{ANTÓNIMOS}

Ineficacia, ineficiencia, devaluar, desajustar, desprecio.

\section{EJEMPLOS}

El proceso de diseño no es lineal, no consiste en una única y simple secuencia directa del análisis a la sintesis y de la sintesis a la evaluación. En la mayoría de los casos prácticos de diseño, es el momento que se ejecuta una cosa y se encuentra otra y se llega a una síntesis, nos podemos percatar que hemos descuidado de analizar alguna otra cosa y hay que volver al principio del ciclo, llegar a una nueva sintesis modificada y, así sucesivamente. En la práctica este ir y venir, de adelantos y retrocesos, se repite varias veces. Sin embargo, entre más tarde se detecta un error tanto más alto es su costo.

Un efecto muy parecido al juego de azar de "serpientes y escaleras", jugado sobre un tablero con casillas donde los participantes compiten por llegar en primer lugar a la meta. Su principal característica es que algunas casillas indican si el participante sube (escalera) o baja (serpiente) ganando o perdiendo, respectivamente, posiciones en el juego. En el juego los casilleros con serpientes siempre indican alguna situación que trae como consecuencia un retroceso. En cambio, las casillas con escaleras son situaciones cuyo resultado siempre ayuda a adelantarse. Es un entretenimiento que enseña valores. Este viaje virtuoso está regido, no por la voluntad y el esfuerzo, sino por el azar, ya que se juega con dados que en última instancia determinan dónde y cómo circular por el camino, sin posibilidad volitiva de caer en la virtud. Lo cual resulta paradójico si lo que se trata es de inculcar el esfuerzo para seguir las enseñanzas de una vida recta y moral. El aprendizaje es sobreponerse a las caídas y seguir jugando reparando los daños sobre la marcha y explotando al máximo los avances rápidos hasta alcanzar la meta final. Se asemeja, en cierta manera, al sistema de lenguaje de Wittgenstein: una escalera que se debe ascender, escalón tras escalón, para dejarlo todo dentro de sí. En el diseño quisiéramos no toparnos con muchas serpientes y sí aprovechar el mayor número de escaleras posibles. Cada evaluación representa un riesgo de retroceso, pero el mayor retroceso puede ser resultado de una evaluación mal hecha, o bien hecha fuera de tiempo, o simplemente no hecha.

\section{Información e investigación}

\section{Definición Diccionario RAE (DENOtACIÓn)} Información (Del lat: informaťo, -ōnis). Acción y efecto de informar. Comunicación o adquisición 
de conocimientos que permiten ampliar o precisar los que se poseen sobre una materia determinada.

Investigación (Del lat. investigatı̆o, -ōnis). Acción y efecto de investigar.

Investigar (Del lat. investigāre). Hacer diligencias para descubrir algo. Realizar actividades intelectuales y experimentales de modo sistemático con el propósito de aumentar los conocimientos sobre una determinada materia.

\section{DESARROLLO O CONSTRUCCIÓN DEL CONCEPTO}

Una de las fases iniciales del proyecto de diseño es la investigación. Es un proceso sistemático que emplea métodos específicos para entender fenómenos o contextos determinados con el objetivo de ampliar el conocimiento del tema a abordar. Los datos que arroja la investigación son registrados de forma rigurosa ya que esto facilitará las etapas posteriores del proceso de investigación (análisis, síntesis y comunicación).

Una vez que se tiene definido el problema. se realiza un el documento inicial de proyecto (brief) en el cual se determina qué información se tiene actualmente, qué información se requerirá para desarrollar el proyecto y qué tipo de investigación se va a hacer. Se determinan también las fuentes a investigar, los métodos que se usarán y, en el caso de investigación primaria, la muestra en dónde se aplicarán los métodos.

Existen dos tipos de información: primaria y secundaria. Su diferencia principal radica en las fuentes que se deberán consultar para obtenerla. Si se consultan libros, catálogos, publicaciones, páginas web, informes empresariales, documentos de estudios ya elaborados, etc., nos arrojarán información secundaria, esto es, emanada de estudios o investigaciones realizadas para otros propósitos, pero de utilidad para nuestro proyecto.

Si se recurre a fuentes primarias vamos directamente con las personas involucradas en el contexto o problemática a estudiar, y dicha información es ad hoc a nuestro proyecto. La gran diferencia, entre la información primaria y secundaria, radica en el hecho de quién y para qué fue realizada la investigación y cuáles fueron los resultados. En las fuentes secundarias, alguien más planteó una investigación para recopilar y generar la información con un enfoque en particular, que pueden ser datos útiles enfocados desde otra perspectiva. Mientras que en las fuentes primarias, el diseñador (investigador) planea su propia investigación, a la medida del proyecto, para recabar la información que necesita con un enfoque específico.

Para hacer investigación primaria existen dos métodos principales: los cuantitativos y los cualitativos. Cada uno es útil para cierto propósito. La información cuantitativa es numérica y estadística que permite al equipo de diseño dar una dimensión física para la toma de decisiones en el proyecto. Mientras que la información cualitativa es útil en el proceso de diseño en la medida que ayuda a comprender por qué las cosas son como son y las razones por las cuales la gente reacciona ante los objetos.

Para hacer investigación, tanto primaria como secundaria, cuantitativa o cualitativa se hace a partir de investigación documental, en bibliotecas $\mathrm{y} / \mathrm{o}$ internet. 
La información es entonces el resultado de un proceso de investigación que va más allá de la obtención de datos concretos. En éste proceso se organizan, jerarquizan, entienden, relacionan, conceptualizan los datos y esto ayuda a incrementar el nivel de comprensión y conocimiento del contexto o problema de diseño, lo que nos ayudará a hacer proyectos más apegados a la realidad, innovadores y viables tecnológicamente.

\section{USOS O ACEPCIONES (ACLARACIONES)}

Es importante que el diseñador adopte el rigor para realizar la investigación primaria y secundaria. Documentar adecuada y sistemáticamente facilitará el análisis de dicha información.

El diseñador se debe preguntar por la pertinencia, no basta con tener la información sino que es indispensable saber para qué le es útil.

\section{SiNóNIMOS}

Investigación: exploración, indagación, averiguación, búsqueda, encuesta, pesquisa, pregunta, sondeo.

Información: declaración, explicación, exposición, afirmación, enunciación, proclamación, confesión, revelación, testimonio, manifiesto, comunicación.

\section{ANTÓNIMOS}

No existe.

\section{EJEMPLOS}

La investigación cuantitativa recurre a técnicas como las encuestas, que a partir de preguntas cerradas y opciones de respuestas indagan sobre datos demográficos, preferencias o posturas concretas. Un censo de población es una encuesta que arroja gran variedad de datos que posteriormente se analizan y cruzan dando información para muchos proyectos.

La investigación cuantitativa recurre a metodologías como la observación y las entrevistas (entre muchas otras). La muestra a la que llegan es más reducida, pero la profundidad de la información recabada es mucho mayor que la que arrojan los cuantitativos. Aquí se indaga sobre las motivaciones, gustos, expectativas, razones, preferencias, etc., haciendo énfasis en los porqués, por lo tanto, la información que se genera llega a ser muy útil en la fase de creación del proyecto de diseño.

\section{Intuición y creatividad}

\section{Definición Diccionario RAE (DENOTACIÓN)}

Intuición (Del lat. mediev. intuitĭo, -ōnis). Facultad de comprender las cosas instantáneamente, sin necesidad de razonamiento. Resultado de intuir. Coloq. presentimiento. Percepción intima e instantánea de una idea o una verdad que aparece como evidente a quien la tiene.

Creatividad (Del lat. Creare). Capacidad y procesos de búsqueda y descubrimiento de soluciones nuevas e inhabituales, pero con sentido, en los diversos ámbitos de la vida.

\section{DESARROLLO O CONSTRUCCIÓN DEL CONCEPTO}

El uso del término intuición en la disciplina del 
diseño industrial está íntimamente ligado al concepto de creatividad, incluso, hay ocasiones en que los términos se confunden al considerarse que un acto intuitivo puede ser parte de un momento creativo. El pensamiento creativo ha permitido al género humano crear y desarrollar las cosas que configuran el medio en que vive. Los diseñadores deberán entrenarse en el ejercicio de la creatividad porque lo que se requiere de ellos es que aporten soluciones siempre diferentes a problemas mil veces planteados. Es ese punto de intuición y de genio que hace que un objeto estética y conceptualmente bien diseñado.

La creatividad es una facultad innata en las personas que la desarrollan más o menos y es uno de los ingredientes clave del diseño. Es la facultad o capacidad humana de producir y transformar la realidad mediante una actitud mental, intencionada alteración de la configuración del entorno con una finalidad práctica prevista: producir respuestas originales a cualquier problema. Es una capacidad humana muy peculiar que puede o no asociarse con una gran habilidad, pero por lo común sólo tiene trascendencia cuando forma parte de una constelación de facultades o impulsos sobresalientes que son los que determinan al individuo creador. La humanidad ha creado objetos y métodos para realizar tareas de maneras nuevas, diversas y distintas para satisfacer propósitos.

En la práctica de los diseñadores industriales, es común escuchar que se habla de una gran intuición por parte de los profesionales dedicados a esta disciplina, sin embargo, este término se utiliza generalmente para justificar porqué una decisión no ha quedado del todo clara. En el Diccionario de la Real Academia Española de la Lengua (RAEL) se dice que intuición es la facultad de comprender las cosas instantáneamente, sin necesidad de razonamiento; por otro lado, razonar es discurrir, ordenando ideas en la mente para llegar a una conclusión; luego entonces, parecería que en la acción de intuir no se tiene un orden claro de ideas. Sin embargo, esta acción no podría llevarse a cabo si no existiera un punto de partida, es decir, si no se contara con información previa. Las soluciones creativas no son productos casuales; se basan en experiencias previas, en informaciones adquiridas y en la aptitud de reconocer los problemas. Es en este punto donde considerar un método para el desarrollo de proyectos de diseño es de gran relevancia, ya que dentro de todos los métodos de diseño se cuenta con una fase de recopilación de información que se analiza y ordena de manera consciente, lo que permite que el diseñador tenga mayor información en el momento de tomar cualquier decisión. Lo anterior, no elimina la capacidad de ordenar intuitivamente la información, lo que podría denominarse como una decisión intuitiva.

Por lo común, se cree que tomar una decisión durante un proyecto de diseño de manera intuitiva implica dejar a la deriva la posibilidad de desarrollar un proyecto objetivo; sin embargo, se podría comenzar a eliminar esta falsa creencia en la que se considera que las decisiones sólo pueden ser tomadas de manera totalmente racional o de manera puramente 
intuitiva; es decir, siempre existirán en la toma de decisiones aspectos objetivos y subjetivos que permean dicha decisión.

\section{USOS O ACEPCIONES (ACLARACIONES)}

Para Greenacre las características básicas del talento creador se pueden describir bajo cuatro enunciados:

- Gran sensibilidad a los estímulos sensoriales.

- Una capacidad excepcional para percibir las relaciones existentes entre varios estímulos.

- Predisposición a una empatía de mayor alcance y de "vibraciones" más profundas que lo normal.

- Integridad de un equipo sensorial motor que sea lo suficiente para permitir la estructuración de las descargas motoras proyectivas que entran en juego.

A partir de lo anterior, podríamos profundizar y señalar que si bien en el proceso de diseño que llevan a cabo los diseñadores pueden encontrarse actos intuitivos y actos creativos, el fin último de estos actos no va encaminado a la expresión personal del diseñador, por lo que dista mucho de la figura del artista con el cual se le confunde.

El diseñador creativo combina la fluidez del conocimiento con la flexibilidad del pensamiento; la originalidad de respuesta con la adecuación a las condiciones imperantes y una sensibilidad intuitiva aguda con la habilidad de realización que produce ideas, actos y obras que se caracterizan por ser nuevas, imprevistas y trascendentes y cuyo resultado ocasiona satisfacción tanto al diseñador como a los demás.

\section{SINÓNIMOS}

Inspiración, instintivo, sagaz, sentimiento, subjetivo, talento.

\section{ANTónIMOS}

Raciocinio, examinar, reflexionar.

\section{EJEMPLOS}

Puesto que el diseño es una actividad creativa, el diseñador con frecuencia debe apoyarse en el pensamiento creativo, en los amplios y misteriosos mecanismos del cerebro humano, tanto a nivel consciente como subconsciente. Para algunos, esta categoría ha ejercido una función más bien negativa, al exagerar el papel que ha tenido, y aún tiene, el componente creativo en el momento de proyectar. Creatividad que celebra, en la esfera de la proyectación, un enfoque irracional, de descomedida confianza en la sola intuición. Así, la intuición dentro de los proyectos de diseño es generalmente vista como un ente negativo, un distractor de la atención del diseñador hacia lo que se cree realmente importante: los aspectos objetivos. Pero, si el diseñador logra entender que el acto de intuir es parte de una gran masa de aspectos, objetivos y subjetivos, que conforman la totalidad no cerrada y compleja del proyecto de diseño, podrá revertir este sesgo negativo y generar un entendimiento positivo acerca del equilibrio dinámico que se da entre lo subjetivo y lo objetivo dentro del acto de diseñar, sabiendo que este acto implica apropiarse y hacer consciente la manera en que somos humanos intuitivos y racionales al mismo tiempo. 


\section{Lluvia de ideas o tormenta cerebral}

\section{Definición Diccionario RAE (DENOTACIÓN)}

La lluvia de ideas (en inglés brainstorming), también denominada tormenta cerebral, es una herramienta de trabajo estructurado grupal que facilita el surgimiento de nuevas ideas sobre un tema o problema determinado. La lluvia de ideas es una técnica de grupo para generar ideas originales en un ambiente relajado.

\section{DESARROLLO O CONSTRUCCIÓN DEL CONCEPTO}

Esta técnica fue descrita por primera vez en 1963 por Alex F. Osborn (1960) en su obra Applied Imagination. En la actualidad es ampliamente utilizada en empresas y en oficinas de diseño. Se trata de formar un grupo de trabajo de 5 a 12 personas, bajo la responsabilidad de un moderador, animador o "distribuidor de juego" - entrenado para el caso-, cuya función consistirá en estimular el surgimiento de ideas nuevas. El grupo puede ser homogéneo o heterogéneo $y$, puede o no ser representativo de un campo especializado. Lo que importa es que la elección de los participantes se efectúe voluntaria y sensatamente, y que corresponda al campo de investigación y a los objetivos fijados.

Estimular a un grupo de personas para que emitan ideas con rapidez, implica seleccionar personas sin inhibiciones para decir ideas, bajola condición de que ninguna sea criticada o descartada. Todas las ideas por más extravagantes que parezcan son bien recibidas. Estas ideas deberán ser registradas y posteriormente evaluadas.
Esta herramienta surge cuando la búsqueda de ideas creativas trascendió a un proceso interactivo de grupo no estructurado que generaba más y mejores ideas que las que los individuos podian producir trabajando de forma independiente, dando oportunidad de hacer sugerencias sobre un determinado asunto y aprovechando la capacidad creativa de los participantes.

Una sesión de brainstorming puede componerse de 4 etapas o momentos:

- La designación de un animador y de una persona que registre las aportaciones de todos a la vista. Para obtener buenos resultados, la actitud del animador debe ser siempre positiva y discreta.

- El animador debe definir clara y simplemente el problema de interés común o la adopción de un tema cualquiera que requiera del pensamiento divergente. Expone las reglas del juego y explica cómo se desarrollará la sesión.

- La fase de producción de ideas, desordenada y abundante. En esta fase no se admite criticar por ningún motivo las ideas de nadie, y expresamente se invita a los participantes a decir, escribir o esquematizar todo lo que se les ocurra, aún lo más descabellado. Se da cuerpo a la célebre idea de Linus Pauling: "La mejor manera de tener una buena idea es tener montones de ideas". Las ideas que se emiten son escritas individualmente por cada participante, pero son comunicadas oralmente o escritas en una pizarra para que todos las tengan presentes. Las 
ideas expuestas desencadenan otras ideas en los participantes.

- La fase de evaluación crítica. Se inicia cuando el animador considera que ya se aportaron suficientes ideas. Si la fase anterior fue el reino de la fluidez, la flexibilidad, originalidad y elaboración, en esta fase el criterio que impera es el de la viabilidad. El grupo discute el material que acaba de producir y, una vez terminada la sesión, el que registró las ideas, clasifica, evalúa y resalta las más promisorias.

El brainstorming aporta al diseñador industrial un proceso para encontrar soluciones que se asemejan en buena parte al modo en que los diseñadores industriales encuentran soluciones a problemas de diseño, es decir, en un momento del desarrollo de una idea, el modo de pensamiento divergente es requerido para desinhibir los factores que eventualmente obstaculizan a la misma.

\section{USOS O ACEPCIONES (ACLARACIONES)}

El brainstorming requiere la colaboración de un equipo que aporte una cantidad considerable de ideas que permita descartar en un proceso de tipo convergente las que no serían viables. Se recurre al brainstorming cuando se busca un detonante que desencadene la fluidez de propuestas o ideas sobre un problema específico. Los principios del brainstorming se basan en el trabajo en grupo y en la liberación de inhibiciones, prohibiendo expresamente cualquier crítica, eliminando los tiempos de discusión (defensa de las propias ideas y ataque de las ajenas).
Es importante no confundir una reunión de trabajo convencional con una sesión de brainstorming. En la primera habla el jefe y conduce la discusión, mientras los demás toman apuntes y tienen una actitud que podemos llamar "respetuosa", si alguien debe proponer ideas es el jefe y todos lo secundarán apoyándolas con juicios propositivos. En la segunda el jefe desaparece, pues su presencia entorpece la libre circulación de ideas. Si el jefe no es de aquellos que ejerce su autoridad a ultranza, puede permanecer en la reunión y debe hacerlo como cualquier otro participante del grupo.

\section{SINÓNIMOS}

Lluvia de ideas, desencadenamiento mental, torbellino de ideas, desinhibición mental, pensamiento divergente.

\section{ANTÓNIMOS}

Inhibición, pensamiento convergente, represión, crítica

\section{EJEMPLOS}

Los diseñadores ingleses Richard Seymour y Dick Powell abordan algunos proyectos con una técnica muy parecida denominada "forja futura", una sesión de intercambio de ideas con el propósito de generar nuevos conceptos sobre productos diversos. El grupo de trabajo está compuesto por consumidores, ingenieros, periodistas, diseñadores y representantes de la empresa cliente. El objetivo es proporcionar una perspectiva de hacia dónde se desarrollaría el mercado de productos que interesan a la compañía. Se despliega una charla 
espontánea entre los participantes donde se plantean diversas ideas sobre lo que se necesita en el ámbito casero. En menos de tres horas Seymour y Powell aterrizan una veintena de nuevos conceptos de productos que desarrollarán en la oficina para llevarlos hasta la etapa de producción.

Tom Kelley (2010) gerente general de IDEO reconoce utilizar la técnica del Brainstorming para el desarrollo de la mayor parte de los proyectos de su empresa. En las salas de reuniones de IDEO donde se lleva a cabo esta técnica tienen carteles que dicen "Alentemos las ideas alocadas", "Generemos una gran cantidad de ideas", "Seamos visuales" (en referencia a hacer diagramas y esquemas que grafiquen ideas). Según Kelley en una sesión se pueden producir más de 100 ideas: "Lo concreto es que una buena sesión de Brainstorming produce un efecto revitalizador, una sensación de infinitas posibilidades". Esa sensación de "combustión grupal espontánea" es la razón que le ha permitido a IDEO encontrar soluciones inusuales a problemas aparentemente irresolubles.

Cualquier problema resulta adecuado para el empleo de esta técnica, siempre que tenga un planteamiento directo y simple. La técnica se puede utilizar en cualquier etapa del proceso: para búsqueda de información, en el planteamiento del problema, en la generación de conceptos de diseño, etc., siempre y cuando los objetivos estén claramente definidos desde el principio. Sin embargo, el brainstorming tiene algunas limitaciones, la más importante es que esta técnica no se puede aplicar a problemas que sólo admiten una solución, es decir, a fases de diseño muy avanzadas en donde se requiere soluciones detalladas, especificas y convergentes.

El brainstorming produce no sólo cantidad sino también calidad, pero lo más sensible es su reconocimiento como un camino extremadamente rápido de generar la variedad de requisitos con los que debe comenzar toda investigación, cuyo objetivo sea la búsqueda de una solución. Se calcula que seis personas pueden generar unas 150 ideas en una hora.

Se recomienda constituir un grupo de personas familiarizadas con el tema desde diferentes áreas del conocimiento y con una adecuada experiencia en la técnica, ésta puede observarse como encaminada a eliminar las inhibiciones que cada persona normalmente tiene a sus respuestas durante una conversación, si se asume el comportamiento de caja negra del ser humano, parece razonable suponer que la eliminación de inhibiciones en la puerta de salida de respuestas mejorará, si no la calidad, si al menos la cantidad de éstas.

La introducción de un periodo preliminar para escribir las ideas es una manera segura de evitar el riesgo de retrasos o fallos producidos por la falta de costumbre de los miembros del grupo en confiar en los demás y poder hablar libremente. El tener ideas en fichas reduce considerablemente el tiempo necesario para clasificar los resultados. 


\section{Método de diseño}

\section{Definición Diccionario RAE (DENOTACIÓN)}

(Del Lat. Methodus, y éste del gr. Méthodos, camino o procedimiento). Modo de hacer o decir con orden una cosa. Modo de obrar o proceder que tiende a formular normas de cualquier procedimiento encaminado a resolver una problemática cualquiera. En esencia se habla de métodos hermenéuticos (los destinados a interpretar el problema) y métodos heurísticos (los propuestos para resolver el problema). Implica siempre cuestiones epistemológicas y lógicas. De la síntesis de estas exigencias se derivan la diversidad de métodos, unos generales y otros específicos de cada disciplina. Aunque las características principales del método sean la generalidad de aplicación en más de un caso y la intersubjetividad en la repetición por diversos individuos, no se ha logrado establecer cuáles métodos son los más adecuados a determinados fines.

\section{DESARROLLO O CONSTRUCCIÓN DEL CONCEPTO}

El diseño no es fruto únicamente de la inspiración, sino que se ejerce siguiendo un método más o menos preciso. En el pasado la complejidad relativa de los problemas de diseño permitía encararlos tan sólo con la intuición. Muchos proyectos modernos de diseño son demasiado complejos para resolverlos de manera satisfactoria mediante métodos antiguos y convencionales (métodos de caja negra). La enorme variedad de técnicas aparecidas en el trabajo y organización del diseño presupone el gran esfuerzo de formalizar visualmente el proceso en busca de unas posibilidades de verificación y control de las sucesivas etapas (métodos de caja transparente). Asimismo, a medida que se incrementa el grado de colaboración humana requerida en la elaboración que determina todo el proceso de diseño de un proyecto, aumenta proporcionalmente la necesidad de formular métodos de trabajo que faciliten al máximo la colaboración y ayuden a traducir a un lenguaje único los miles de datos y propuestas provenientes de los más diversos campos y permitir, incluso, revertir las correcciones con que son afectados estos campos por una propuesta aparentemente aislada. Además de organizar el proceso de diseño puede facilitarlo, también el método resulta útil como argumento, mantiene un cierto valor táctico para subrayar el razonamiento del diseñador. La situación del diseño se ha vuelto más compleja, fundamentalmente por factores internos y externos a él. ¿Hasta dónde se puede estructurar un método que permita guiar al diseñador, sin que sea un lastre a su creatividad? En realidad, la magnitud de cada problema define su método adecuado, dado el carácter instrumental y no concluyente de éstos. El método nos da una autoconciencia, asegurándonos así la posibilidad de autocorregir el proceso, de enseñarlo mejor al discípulo. Permite investigar en la práctica el proceso y permite corregir la práctica profesional.

\section{USOS O ACEPCIONES (ACLARACIONES)}

Con frecuencia son confundidos método con metodología; esto es, se dice "las metodologías" (en plural), para designar diversos métodos, cuando 
en realidad existe una sola metodología (en singular) y no varias, entendido ésta como el estudio de los métodos (en plural). Una confusión parecida suscita los términos técnica, estrategia, modelo, teoria, procedimiento y fase. Es común oír decir a los diseñadores que "llevaron a cabo un método", cuando, en realidad, lo que hicieron fue aplicar una técnica en cierta fase del proceso de diseño. Cuando autores como Christopher Jones (1978) o Nigel Cross (1999) hablan sobre "métodos de diseño" lo hacen para describir las técnicas y estrategias más utilizadas en el diseño, dentro de las cuales, obviamente, está el dibujo. Algo semejante sucede cuando alguien dice que "ha aplicado una metodología", cuando simplemente lo que hizo fue seguir los pasos e indicaciones de un método en particular, sin que exista un estudio de la estructura general de los métodos de diseño. Es general, también, la confusión que produce la palabra proceso cuando se relaciona con el método en el diseño. A primera vista hablar de método implica siempre un determinado proceso. El proceso como sucesión de actos dirigidos a la consecución de objetivos, habla de una diacronía; es decir, de una cadena de acciones ubicada en el tiempo, sin atender básicamente a la teoría que genera dichas acciones. El proceso habla de qué hacer y cuándo hacerlo, sin importar el para qué hacer ni el por qué hacerlo. El método de diseño, en cambio, tiene que ver con todos estos aspectos que incluyen toda una teoría que tiene la misión de explicar con claridad la razón de cada una de las fases del proceso y detalla, al mismo tiempo, la estructura sincrónica de las mismas.

\section{SINÓNIMOS}

Procedimiento, proceso, programa, sistema, disciplina, estrategia, técnicas, regla, orden, régimen, plan, costumbre, hábito.

\section{ANTÓNIMOS}

Desorden, desconcierto, anarquía, intuición, caos.

\section{EJEMPLOS}

El método es una gramática de acciones basada en el análisis de la conducta organizada con fines determinados. Como conducta planeada, sistemática y controlada, el método viene siendo una selección específica de acciones planificadas. Es una característica particular de un grupo de actividades que tienen un carácter no tanto descriptivo sino normativo. Su justificación proviene más bien de su papel instrumental. El método como tal, es una ayuda para determinar la sucesión de acciones (cuándo hacer tal o cual cosa), el contenido de las mismas (qué hay que hacer) y para definir los procedimientos especificos que hay que utilizar (cómo hacer, qué técnicas y estrategias emplear). Debe suministrar un marco dentro del cual ha de ajustarse el diseño, permitiendo entresacar la información relevante y la selección de alternativas para la toma de decisiones. 


\section{Problema de diseño}

\section{Definición Diccionario RAE (DENOtACIÓN)}

Problema (Del lat. problèma, y este del gr. $\pi \varrho o ́ \beta \lambda \eta \mu \alpha)$. Cuestión o punto discutible que se trata de aclarar o resolver. Situación de difícil solución. Proposición dirigida a averiguar el modo de obtener un resultado cuando ciertos datos son conocidos. Conjunto de hechos o circunstancias que dificultan la consecución de algún fin. Planteamiento de una situación cuya respuesta desconocida debe obtenerse a través de métodos científicos.

\section{DESARROLLO O CONSTRUCCIÓN DEL CONCEPTO}

Todo parece confirmar la pasión del hombre por resolver problemas estrechamente vinculada a su voluntad de sobrevivir. Sobrevive gracias a que es un solucionador de problemas. Sin embargo, podríamos decir que la característica más distintiva del hombre no es su capacidad de resolver problemas, sino más bien su capacidad de planteárselos.

El mérito de haber resuelto un problema - sobre todo si se trata de un problema relativamente complejo- en gran parte corre parejo con el mérito de haber sabido plantearlo o definirlo de la manera más adecuada ¿Qué significa plantear un problema? Ante todo significa, como es obvio, aislar la existencia de un problema y seleccionar los medios necesarios para su solución.

Un problema es una determinada cuestión o asunto que requiere una solución. En el caso del diseño industrial se trata de que con la solución del problema se aporten beneficios a la sociedad.
Los problemas son las preguntas que planteamos cuando reflexionamos sobre la manera de superar las dificultades. No podemos diseñar hasta no haber descubierto las dificultades a las que nos vamos a enfrentar. El punto de partida de una investigación es la existencia de una situación conflictiva que ha llamado la atención del o los diseñadores y que - a su juicio- requiere ser investigada para esclarecerla, mejorarla, hacer propuestas, resolverla, etc., es decir, para pasar a algún tipo de acción posterior. Los problemas de diseño son de un tipo bastante excepcional. No son como los problemas científicos, matemáticos o lógicos, que por lo general necesitan la "prueba" de una hipótesis. No son como los crucigramas o las adivinanzas, que tienen una única respuesta correcta. No son como los problemas del pintor o del compositor, que trabaja principalmente para cumplir con objetivos y pautas autoimpuestas. Los problemas de diseño con frecuencia contienen aspectos de todos estos tipos de problemas, pero son, no obstante, diferentes. Pero hay que saber distinguir cuáles son los problemas que pueden ser resueltos con la intervención del diseño y cuáles no.

Un problema de diseño es aquella cuestión que nos genera curiosidad, que demanda una $o$ varias soluciones y que permite generar proyectos de diseño a partir de éste. Antes de desplegar cualquier intento de encontrar soluciones posibles para un problema, se debe identificar y plantear el problema de diseño. Es común que los diseñadores se vean tentados de fijar en la mente, algún concepto de diseño que parece proporcionar una solución factible antes de que 
el problema real se comprenda cabalmente. La información que tenemos disponible procede de un encargo, pero el encargo puede no estar debidamente sustentado en el problema real. Existen dos posturas frente al problema del diseño: la primera es asumir éste como el punto de partida del proyecto. Si es así, entonces, el problema ya está identificado y muchas veces se enuncia a partir de una necesidad detectada, se continúa con investigación (primaria y secundaria) y se pasa a la etapa de ideación para proponer soluciones.

La segunda postura es la de, a partir de algún pretexto o inquietud, realizar una investigación para detectar los problemas o necesidades, enunciarlos y emprender el proyecto de diseño. En este último caso lo que se hace es investigar, analizar y sintetizar los aspectos relevantes para entender la situación (es decir, todo un contexto complejo de actores y relaciones) y a partir de esto identificar los componentes relevantes de la problemática para así relacionarlos entre sí y entender la complejidad de la situación y poder enunciar adecuadamente un problema del cual partirá el proceso de diseño.

\section{USOS O ACEPCIONES (ACLARACIONES)}

El diseñador industrial es, sin duda, un solucionador de problemas acotados, tanto en la elección del problema como en la solución. El diseñador no trabaja para sí mismo, sino para personas o empresas que tienen la necesidad de crear un objeto. Estas personas recurren al diseñador para que éste les proponga soluciones, así los problemas son planteados desde afuera del diseño y, con no menos frecuencia, las soluciones también.

Las dificultades se deben en gran medida a nuestra falta de información sobre las verdaderas necesidades y tendencias del mercado, en parte porque estamos incapacitados para hacer predicciones certeras para situaciones futuras y no tenemos un modelo confiable para hacerlas. En principio, queremos saber quiénes serán los posibles consumidores y en qué categorias se les puede clasificar. Para elaborar más a fondo la definición del problema, deseamos detallar las necesidades, precisamente, en función de la manera cómo el futuro usuario empleará el producto.

Se da por sentado que hemos recibido una exposición rudimentaria de las necesidades. Por rudimentaria entendemos que la exposición del encargo representa una opinión basada principalmente en observaciones causales, pero no confirmadas por una evidencia organizada. Tales opiniones son valiosas como puntos de partida, cuando provienen de personas que han tenido la oportunidad y poseen la capacidad de hacer observaciones y de apoyarlas con juicios bien deliberados. A menudo la industria tiende a inventar falsas necesidades para poder fabricar y vender nuevos productos.

La mayoría de los diseñadores creen que los problemas ya han sido suficientemente definidos por sus clientes. Pero esto no es en absoluto suficiente. Los problemas de diseño rara vez se presentan ya formulados con una exposición concisa y clara de los factores que en ellos intervienen, e impregnados de indicios elocuentes 
que señalen cuál es la solución acertada. Por lo general, ni siquiera se sabe con claridad si se trata de un problema, o de su manifestación, o de varios, y en tal caso, en qué consisten. El diseñador no recibe un problema, sino una situación problemática, situación que puede tener muchos elementos de perplejidad relacionados entre sí en formas complicadas y obscuras.

Por tanto, es necesario empezar por la definición del problema, que servirá también para conocer los límites en los que deberá moverse el proyectista. Los tipos de problemas pueden ser ordenados a partir de estar bien definidos o mal definidos. Un problema está bien definido o estructurado cuando las variables que lo componen están cerradas, y está mal definido cuando sus variables están abiertas. Los estados iniciales (entradas) y terminales (salidas) pueden estar más o menos definidos.

Lo primero que hay que hacer es definir el problema en su conjunto y después puede ser descompuesto en sus elementos. Esta operación facilita la proyectación porque tiende a descubrir los pequeños problemas particulares que se ocultan tras los subproblemas sin descuidar el conjunto. El principio de descomponer un problema en sus elementos para poder analizarlo procede del método cartesiano. De este medio de perplejidad es de donde habrá que derivar definiciones claras de los subproblemas relevantes.

Cuando se trabaja con la situación problemática, usualmente descubrimos que no sabemos lo suficiente sobre los factores que lo componen. Intentamos enfocar nuestras metas, aunque éstas pueden ser objeto de rectificación a la luz de futuras evidencias. A medida que se comprende la situación problemática, se va siendo capaz de percibir las dificultades reales y ya se pueden comenzar a formular preguntas adecuadas. En un principio las preguntas del tipo ¿quién? ¿qué? y ¿cuándo?, variedad que sirve para detectar los factores importantes. Posteriormente, se elaboran más del tipo ¿cómo? ¿porqué?, adecuado para clarificar las relaciones causales y correctivas.

Las interrogantes pueden ahora reunirse y combinarse en una pauta que constituye una enunciación explícita del problema. Ésta expone con claridad qué metas deben alcanzarse; qué dificultades tendrán que superarse; de qué recursos se dispone; qué restricciones circunscribirán a cualquiera de las soluciones aceptables y, por último, qué criterios deben emplearse para juzgar la bondad de una posible solución.

Cada problema tiene una configuración estructural que le es propia. Los problemas de diseño normalmente se originan como alguna forma de estructuración o planteamiento que alguien -el cliente o la gerencia de la compañía- presenta al diseñador. En la praxis, el diseñador raramente puede invalidar dicho encargo, sin ejercer cierta crítica razonada. El pensamiento consiste en imaginar y comprender los rasgos y requerimientos estructurales; proceder de acuerdo a éstos, por tanto, cambiar la situación inicial en una situación final que solucione el problema de diseño.

Se precisan datos sobre estos factores y se buscan diversas fuentes de información. Diagnosticar, definir, preparar, llevan implícito un 
entendimiento del problema y una enunciación clara de las metas que se proponen alcanzar quien pretenda resolver el problema. Se procura detectar la jerarquía estructural, separar los rasgos periféricos de los esenciales de esa estructura y, en general, buscar verdades estructurales y no fragmentarias.

El concepto de situación problemática nos aproxima a la idea de situaciones reales de una profesión, donde el diseñador construye, modifica o refuta los conocimientos contextualizados. ¿Cuáles son las características y constituyentes de una situación problemática? ¿Cómo debemos proceder para planear situaciones problemáticas o significativas?

El concepto de situación problemática es una noción de uso común que designa frecuentemente el entorno dentro del cual se realiza una actividad o se desarrolla un acontecimiento. Se habla de situaciones de la vida cotidiana en donde éstas son dictadas por los acontecimientos a los cuales nos enfrentamos día con día. Se podría resumir así lo antes dicho:

1. La situación problemática no es del orden del gesto o tarea elemental (como apretar un botón, manipular un tenedor, etc.); ésta necesita una movilización cognitiva, gestual y/o socio-afectivà de los diversos actores que conforman la situación.

2. Los problemas de diseño contienen objetivos inicialmente conocidos, pero también desconocidos, tanto criterios objetivos como subjetivos.

3. Hay una producción esperada, claramente identificable: la solución de un problema, un objeto funcional, un plan de acción. La situación no está cerrada, pues aunque esperamos cierto comportamiento, el diseñador construye a su manera las diversas soluciones.

4. La resolución de los problemas de diseño implica tanto descubrir cómo solucionar problemas; conlleva tanto esfuerzos conscientes como subconscientes; tanto acciones planificadas como espontáneas.

5. El término "situación problemática" no es exactamente una situación controlable organizada por el promotor del diseño, se trata de una situación significativa a la que el diseñador se enfrenta.

\section{SiNóNIMOS}

Duda, pregunta, cuestión, incógnita, dilema, ejercicio, enigma, perplejidad rompecabezas, asunto.

\section{ANTÓNIMO}

Solución.

\section{EJEMPLOS}

Los problemas de diseño que ya tienen solución no son problemas. Un problema es una situación conflictiva que induce a una curiosidad epistémica. Una situación problemática es una situación de estimulación adversa, de privación y de conflicto donde el organismo no dispone inmediatamente de un comportamiento que reduzca la privación u ofrezca una salida viable. Los problemas son susceptibles de plantearse como preguntas, cuya respuesta sería la solución. En la 
PROCESO... 84 CONCEPTOS CLAVE PARA LA FORMACIÓN DEL DISEÑADOR INDUSTRIAL • PARTE I

primera etapa del proceso se hace un esfuerzo por entender el problema de diseño, éste es una situación de perplejidad. El esfuerzo debe orientarse a entender qué elementos generan perplejidades en la situación.

\section{Proceso de diseño}

\section{Definición Diccionario RAE (DENOTACIÓN)}

La palabra proceso tiene su origen en el término latino processus. Acción de ir hacia adelante. Un proceso es un conjunto de actividades o eventos (coordinados u organizados) que se realizan o suceden (alternativa o simultáneamente) bajo diferentes etapas con un fin determinado. Implica el transcurso del tiempo en un contexto determinado. Conjunto de operaciones a que se somete una cosa para transformarla. Este término tiene significados diferentes según la rama de la ciencia o la técnica en que se utilice.

\section{DESARROLLO O CONSTRUCCIÓN DEL CONCEPTO}

Todo aquel que emprenda un trabajo debe poseer, por más mínima que sea, una pauta de acción. Cualquier trabajo profesional puede definirse dentro de un proceso de trabajo, concepto común a muchas formas de labor. En el acto de diseñar, de proyectar, el hombre decide su futuro material. De ahí se deduce que el estudio de los procesos que los diseñadores y otras profesiones similares han utilizado para la consecución de los objetivos sea de vital importancia.

El diseñador como profesional debe estar atento a las relaciones del hombre con las cosas y el contexto donde interactúan, detectando problemas que podrían ser resueltos mediante el diseño. El proceso de diseño es un conjunto de relaciones que se establecen entre el diseñador, el problema planteado y la resolución del mismo. Para que funcione el proceso, el diseñador habrá de investigar recogiendo informaciones diversas, seleccionado los datos pertinentes que son indispensables para la acometida creativa. La primera fuente de información proviene del cliente o de la empresa que lo contrata. Se comprende la importancia que tiene para el diseñador captar correctamente toda esta información. Será esencial para enfocar en la dirección apropiada lo que se va a diseñar. Un error de interpretación en el punto de partida terminará por reflejarse en etapas posteriores.

La creatividad propiamente dicha sólo empieza cuando toda la información ha sido entendida y clasificada. El primer paso creativo consiste en analizar a fondo toda la información recibida. Esta creatividad dependerá de lo que ya se conoce (experiencia previa) y del incremento de la información que se pueda lograr (conocimiento adquirido). El punto de partida se presenta cuando el diseñador industrial se sumerge en un proceso creativo y se esfuerza en desarrollar un producto innovador, un producto industrial que da solución a un problema previamente planteado. Ante todo se espera del diseñador la aptitud de hallar soluciones nuevas para productos industriales. La creatividad del diseñador se manifiesta en que, basándose en conocimientos, habilidades y actitudes, es capaz de establecer 
nuevas relaciones entre diversos elementos y características formales.

El conocimiento de un hecho o la identificación de una situación problemática es el supuesto sobre el que se asienta toda la actividad de diseño. Hacer descubrimientos y formular hipótesis forma parte del tipo de tareas de resolución de problemas. El diseñador decide sobre un ente que se materializará a través de un largo proceso de toma de decisiones relativas a aspectos funcionales, técnico-productivos y comerciales. Se pretende contar con una prefiguración muy exacta de lo que se va realizar. Los bocetos, planos, dibujos, maquetas y prototipos funcionales explican muy bien el desarrollo de un proyecto industrial. Los riesgos y las pérdidas que supone la fabricación de un producto erróneo o defectuoso reclaman modelos anticipativos muy sofisticados que eviten los errores antes de que éstos se produzcan.

Todos hemos "sentido" la necesidad de establecer un proceso de diseño. Lo puntos más importantes serían:

- Existe un proceso de diseño.

- Es importante definir y entender el proceso de diseño en palabras que sean útiles y significativas para cada quién.

- Existe un proceso lógico a través del cual se puede clasificar cada parte del trabajo de diseño y que se asemeja al de la solución de los problemas en general.

En la actividad de diseño, entendida como creativa, existe un proceso, esto es, la actividad requiere de una secuencia organizada que encamine las acciones de una manera eficaz y convenientemente relacionadas entre sí. El proceso, como sucesión de actos dirigidos a la consecución de objetivos, se expresa en sentido diacrónico, es decir, una cadena de acciones ubicadas en el tiempo cuya principal característica es la de imponer un orden en las tareas para proyectar la forma.

El carácter del proceso de diseño es descriptivo. Habla del "qué" hacer y del "cuándo" hacer las cosas. Este ordenamiento de las labores implica tanto esfuerzos conscientes como inconscientes, tanto elementos de orden subjetivo fincados en la intuición, como elementos propios del razonamiento lógico, para reunir, manejar y exponer todos los factores condicionantes, para además combinar, articular e integrar los elementos de la respuesta formal, sometiendo, evaluando y optimizando ésta de acuerdo con el comportamiento real del objeto en la producción, el mercado, así como en el uso y al llegar su obsolescencia.

Todo proceso puede ser descrito por etapas, es decir, fases cronológicas que el proceso ha de seguir. Una de las observaciones más sencillas y comunes, en la que muchos teóricos están de acuerdo, es la introducción en el proceso de diseño de varias etapas esenciales, entre otras: análisis del problema, sintesis de soluciones del problema, evaluación o valoración de las alternativas y realización de la solución seleccionada. Éstas pueden definirse con simples oraciones como "dividir el problema en partes", "colocar las piezas en otras disposiciones", "valuar las diversas composiciones" y "formalizar 
para poner a prueba y descubrir las consecuencias de la nueva organización en la práctica".

Identificación y análisis del problema. Constituye el punto de partida y la motivación inicial para desarrollar un proceso de diseño. En esta primera etapa se hace un esfuerzo por entender el problema como una situación de perplejidad que el diseño puede solucionar. El esfuerzo debe orientarse a entender qué elemento es el que engendra perplejidad en la situación. Se precisan datos sobre los factores de la perplejidad de la situación y se buscan en diferentes fuentes de información. En esta primera etapa las acciones de diagnosticar, definir y preparar llevan todas implícitamente un entendimiento del problema y una enunciación explícita de las metas que se propone alcanzar quien pretende resolver el problema.

Sintesis de soluciones. En esta fase se elaboran ideas diversas que sinteticen las diversas posibilidades para resolver el problema en cuestión. Existe un esfuerzo por encontrar soluciones con un cierto número de alternativas plausibles. Las técnicas se encaminan a la creación de conceptos, que siempre conducen a nuevas combinaciones. De alguna manera, bajo ciertas condiciones favorables, la mente es capaz de sintetizar soluciones factibles. Redefinir metafóricamente conceptos abstractos ayuda a la generación de alternativas. En esta fase creativa es esencial que el diseñador industrial realice bocetos o construya modelos de cada una de las alternativas de solución ideadas. Las primeras ideas que imaginamos suelen ser simples escarceos que, aunque no conviene tomar muy en serio, forman parte de la gimnasia creativa. Sin embargo, en muchas ocasiones, en problemas sencillos la mejor idea es la primera. Necesitamos muchas ideas de partida, unas más disparatadas que otras, que en el siguiente paso estarán sujetas a una valoración más rigurosa que descarte las que no resulten pertinentes a los objetivos planteados.

Valoración de alternativas. Tercera etapa encaminada a seleccionar una de las alternativas juzgando su validez a la luz de las metas que se fijaron de antemano, para lo cual se realiza un examen repentino de las soluciones presentadas. Para apreciar en lo que vale una idea que nos parece interesante, es menester compararla con otras. De entre las alternativas elaboradas puede sondearse cuál es la más prometedora confrontándolas con los valores exigidos previamente fijados. Se vuelve esencial conseguir una expresión más formal que las simples imágenes mentales de la etapa anterior, esto es, enunciar la solución como una hipótesis que se puede probar y juzgar sobre su concordancia con el mundo externo. La idea va así depurándose como resultado de las múltiples mutaciones que sufre en ese continuo cotejo con las exigencias del proyecto.

Realización de la solución. El último paso del proceso de diseño es concretar la solución seleccionada como la mejor para el problema. De unos cuantos dibujos esquemáticos haremos emerger la solución, cada vez con más precisión y claridad. Los primeros dibujos contienen una idea global que puede llegar a funcionar. Se trata, entonces, de desmenuzar esa idea global y 
atender a cada una de sus partes, como si éstas fueran un diseño autónomo. Esta idea global es de nuevo redefinida y perfeccionada a través de la especificación técnica de cada elemento de la solución que establece una transcripción extensiva del producto. El problema técnico es una convergencia de las funciones en una unidad estructural coherente y armoniosa. En el objeto perfectamente acabado cada elemento debe cumplir lo mejor posible su función propia pero correlacionada con los demás elementos. La integración al conjunto plantea una serie de conflictos a resolver que se denominan como técnicos y que, de hecho, son problemas de compatibilidad entre los elementos del sistema. El objeto existe como un tipo específico obtenido al término de un proceso convergente que va del modo abstracto al modo concreto, coherente consigo mismo y coherente con el contexto donde se genera el problema. Esta etapa de concreción detallada exige pasar del dibujo esquemático a la precisión de los planos técnicos. Sólo el delineado exacto desde todos sus ángulos, como lo permite el dibujo técnico, puede decirnos si las partes encajan en el todo y viceversa. A pesar de la calidad de estas representaciones, no son una realidad tangible del esfuerzo de concreción formal que el diseño requiere. Para ello podemos recurrir a modelos volumétricos que nos permitan tocar y manejar el objeto verificando si corresponde a lo esperado, tanto física, funcional y morfológicamente. El resultado es un proyecto de diseño que finaliza con la construcción del prototipo que sirve para hacer las últimas evaluaciones y la toma de decisiones para la entrada a producción del objeto industrial.

Gracias a todo esto será factible pasar de la traducción lingüistica de la necesidad a la transcripción extensiva del objeto como satisfactor. Todo el proceso, desde la demanda verbal hasta la propuesta formal, es el campo de la racionalización que se ha depositado en la práctica profesional de los diseñadores. Cada etapa del proceso implica una investigación o desarrollo de búsqueda de información que aportará datos en todas las fases del procedimiento. Para el diseñador comprometido en la práctica, la investigación de diseño implica, en primer lugar, un proceso de búsqueda de información, inmediatamente después de ideas, de materiales y procesos, y por último, de soluciones.

\section{USOS O ACEPCIONES (ACLARACIONES)}

Existen muchos intentos de elaborar modelos del proceso de diseño. Algunos de éstos sólo describen las secuencias de actividades que ocurren típicamente en el diseño; otros modelos intentan prescribir un patrón mejor o más apropiado de actividades. Los modelos descriptivos del proceso de diseño generalmente hacen énfasis en la importancia de elaborar conceptos de solución en una etapa temprana del proceso, estas conjeturas iniciales de solución se someten a una evaluación, refinamiento y desarrollo de la más prometedora.

El diseño tiene dos partes imbricadas en su proceso: la interpretación y la invención. La hermenéutica es la parte del proceso que se encarga de interpretar y la heurística es la 
parte del diseño que lleva al descubrimiento y la invención. En otras palabras, para el diseño, la hermenéutica o técnica de la interpretación se contiene en el análisis o vía deductiva y la heurística o arte de la invención se centra en la sintesis o vía inductiva. Entre estos dos momentos, uno hermenéutico, analítico y deductivo, y otro heurístico, sintético e inductivo, existe un "punto neutro", un acto poco conocido, casi instintivo que es la intuición. Buena parte del proceso consiste en revelar, en hacer visible un concepto intuido. Sin esa noción interiorizada la búsqueda de ideas no tendría horizonte.

\section{SINÓNIMOS}

Procesamiento, transcurso, paso, desarrollo, progreso, transformación, evolución.

\section{ANTÓNIMO}

No existe.

\section{EJEMPLOS}

Los modelos del proceso de diseño se elaboran bajo la forma de un diagrama de flujo, con ciclos consecutivos y de retroalimentación. El predominio de diagramas de bloque, matrices y redes de muchos tipos como medio para explicar el proceso de diseño hace que éste sea su rasgo característico. Este desarrollo no se lleva a cabo de manera secuencial, sino que se presenta en un vaivén a lo largo del proceso de diseño, una especie de aproximaciones que lo retroalimentan constantemente.

\section{Propiedad intelectual}

\section{Definición Diccionario RAE (DEnOtación)} Propiedad. En Derecho, la propiedad es el poder directo e inmediato sobre un objeto o bien, por la que se atribuye a su titular la capacidad de disponer del mismo, sin más limitaciones que las que imponga la ley. Es el derecho real que implica el ejercicio de las facultades jurídicas más amplias que el ordenamiento jurídico concede sobre un bien. El objeto del derecho de propiedad está constituido por todos los bienes susceptibles de apropiación. Para que se cumpla tal condición, en general, se requieren tres condiciones: que el bien sea útil, ya que si no lo fuera, carecería de fin la apropiación; que el bien exista en cantidad limitada, y que sea susceptible de ocupación, porque de otro modo no podrá actuarse.

Intelectual: Relativo al entendimiento o al intelecto. Se aplica al trabajo o actividad que requiere especialmente el empleo de la inteligencia. La actividad intelectual es aquella dedicada al pensamiento que tiene una dimensión y una repercusión pública que se considera muy valiosa. El intelectual desarrolla su intelecto no como mera vanagloria, sino como una minúscula contribución al progreso del mundo. El intelectual medita, reflexiona, discurre, se inspira, goza, busca, investiga, analiza, discierne, desmenuza, razona, contrapone conceptos, filosofa, organiza las ideas, proyecta, imagina, especula, atribuye causas a los efectos y efectos a las causas, interconecta fenómenos. En este sentido, el diseñador es un intelectual, al pensar 
activamente, interviene mediante la reflexión, exigiendo replantear, viendo las cosas desde otro punto de vista, contribuye a legitimar o deslegitimar ciertas prácticas de empresas e instituciones y, en definitiva, pone en cuestión el discurso y el mundo que le viene dado. El diseñador, al abrirse a las interpretaciones alternativas de la realidad, amplia la perspectiva de los ciudadanos y trata de transformar el mundo mediante sus obras o creaciones.

La propiedad intelectual es el conjunto de derechos que corresponden a los autores y a otros titulares (artistas, productores, organismos, diseñadores, etc.) respecto de las obras y prestaciones fruto de su creación. Supone el reconocimiento de un derecho particular a favor de un autor $u$ otros titulares de derechos, sobre las obras del intelecto humano.

La propiedad intelectual es un derecho patrimonial de carácter exclusivo que otorga el Estado por un tiempo determinado para usar o explotar en forma industrial y comercial las invenciones o innovaciones, tales como un producto técnicamente nuevo, una mejora a una máquina o aparato, un diseño original para hacer más útil o atractivo un producto o un proceso de fabricación novedoso; también tiene que ver con la capacidad creativa de la mente: las invenciones, las obras literarias y artísticas, los símbolos, los nombres, las imágenes y privilegios. El titular de la propiedad intelectual tiene la facultad para evitar que cualquier persona tenga acceso o haga uso de su propiedad sin su consentimiento.

\section{DESARROLLO O CONSTRUCCIÓN DEL CONCEPTO}

En México, la autoridad que se encarga de administrar todos estos derechos es la Secretaría de Economía a través del Instituto Mexicano de la Propiedad Intelectual (IMPI) y la ley que rige la materia es la Ley de Propiedad Industrial (LPI), su reglamento y las reglas para la presentación de solicitudes. Las disposiciones de esta Ley son de orden público y de observancia general en toda la república, sin perjuicio de lo establecido en los Tratados Internacionales de los que México sea parte. Su aplicación administrativa corresponde al Ejecutivo Federal por conducto del IMPI.

Esta institución tiene como objetivo aplicar el reglamento, proteger los derechos de propiedad industrial y promover y difundir los beneficios que ésta ofrece para apoyar la actividad inventiva y comercial de nuestro país, impulsando la creación y desarrollo de nuevas tecnologias en beneficio de toda la sociedad.

La propiedad industrial es una de las dos partes que conforman la propiedad intelectual, la otra es la producción autoral que se refiere a los derechos de autor.

La propiedad industrial protege:

- Invenciones patentables, modelos de utilidad, diseños industriales y esquemas de trazado de circuitos, y

- Los signos distintivos como son: marcas, avisos y nombres comerciales y las denominaciones de origen.

La propiedad industrial debe estimular a las empresas a impulsar mejoras, tanto en sus procesos de producción y en los productos mismos, 
como en las formas de comercialización que utilizan en sus actividades, para reforzar su competitividad y obtener un mayor beneficio económico.

\section{USOS O ACEPCIONES (ACLARACIONES)}

Para el IMPI los diseños industriales comprenden:

- Los dibujos industriales, que son toda combinación de figuras, líneas o colores que se incorporen a un producto industrial con fines de ornamentación y que le den un aspecto peculiar propio, $y$

- Los modelos industriales, constituidos por toda forma tridimensional que sirva de tipo o patrón para la fabricación de un producto industrial, que le dé apariencia especial en cuanto no implique efectos técnicos.

Condiciones que deben satisfacerse:

- El diseño (sea modelo o dibujo) debe ser nuevo, es decir, de creación independiente, y que difiera en grado significativo de diseños conocidos o de combinaciones de características comunes de diseños a nivel mundial.

- El diseño (sea dibujo o modelo) debe ser utilizado o producido para la explotación industrial.

Se consideran nuevos los diseños que sean de creación independiente y difieran en grado significativo de diseños conocidos o de combinaciones de características comunes. Nuevo, a todo aquello que no se encuentra en el estado de la técnica; estado de la técnica, al conjunto de conocimientos técnicos que se han hecho públicos mediante una descripción oral o escrita, por la explotación o por cualquier otro medio de difusión o información, en el país o en el extranjero; aplicación industrial a la posibilidad de que una invención pueda ser producida o utilizada en cualquier rama de la actividad económica.

En México èl diseño sólo está protegido contra el uso no autorizado por su titular. La protección de los derechos de propiedad industrial únicamente se otorga en el país donde está solicitada y concedida. Si se desea la misma protección de los derechos de propiedad industrial en el extranjero, se deberá presentar la solicitud en cada país, reclamando el derecho de prioridad (art. 40 y 41 de la Ley de Propiedad Industrial).

\section{SINÓNIMOS}

Propiedad: adquisición, apropiación, disfrute, disposición, goce, legitimidad, ocupación, participación, patrimonio, pertenencia, posesión, usufructo, tenencia.

Intelectual: analítico, capacidad, discernimiento, desmenuzamiento, entendimiento, especulación, intelecto, inteligencia, investigación, imaginación, meditación, mentalidad, pensamiento, reflexión, razonamiento.

\section{ANTÓNIMOS}

Ausencia, carencia, depauperación, desavenencia, escasez, limitación, mengua, miseria, incomprensión, indigencia, pobreza, torpeza, estupidez.

\section{EJEMPLOS}

La protección conferida a un diseño industrial no comprenderá los elementos o características que estuviesen dictados únicamente por 
consideraciones de orden técnico o por la realización de una función técnica, y que no incorporan ningún aporte arbitrario del diseñador, ni aquellos elementos o caracteristicas cuya reproducción exacta fuera necesaria para permitir que el producto que incorpora el diseño sea montado mecánicamente o conectado con otro producto del cual constituya una parte o pieza integrante, esta limitación no se aplicará tratándose de productos en los cuales el diseño radica en una forma destinada a permitir el montaje o la conexión múltiple de los productos a su conexión dentro de un sistema modular. No se protegerá un diseño industrial cuando su aspecto comprenda únicamente los elementos o caracteristicas a que se refiere el párrafo anterior.

\section{Satisfacción}

\section{Definición Diccionario RAE (DENOTACIÓN)}

(Del lat. Satisfactio-õnis) acción y efecto de satisfacer o satisfacerse. Razón, acción o modo con que se sosiega y responde enteramente a una queja, sentimiento o razón contraria. Presunción, vanagloria, confianza o seguridad del ánimo. Cumplimento del deseo o del gusto. A gusto de alguien cumplidamente. Una de las tres partes del sacramento de la penitencia, que consiste en pagar con obras de penitencia la pena debida por las culpas cometidas.

\section{DESARROLLO O CONSTRUCCIÓN DEL CONCEPTO} La satisfacción es un estado de la mente producido por una mayor o menor optimización de la retroalimentación cerebral, en donde las diferentes regiones compensan su potencial energético, dando la sensación de plenitud e inapetencia extrema. Esta dinámica contribuye a sostener un estado armonioso dentro de lo que es el funcionamiento mental.

La satisfacción es siempre con algo o con alguien que tiene que ver, a su vez, con algo que se quiere, que se espera, que se desea. Para que exista satisfacción como algo sentido en una persona, debe haber al menos una intención en otro alguien de realizar una acción determinada provocadora de un determinado resultado que sea valorado como positivo o no, como satisfactor o no.

Desde el diseño industrial, definir la satisfacción como el grado en que se atienden o no las expectativas de los consumidores o usuarios, supone incluir factores subjetivos relacionados con los juicios de las personas que reciben el servicio. Es una definición basada en la percepción de los clientes y en la satisfacción de sus expectativas, esto es importante para conocer qué necesitan los usuarios y los consumidores.

La mayoría de los autores que definen la satisfacción del usuario coinciden en que contempla:

- La existencia de un objetivo que el consumidor desea alcanzar.

- La consecución de este objetivo, sólo puede ser juzgado tomando como referencia un estándar de comparación.

- El proceso de evaluación de la satisfacción implica como mínimo la intervención de dos estímulos: un resultado y una referencia o estándar de comparación. 


\section{USOS O ACEPCIONES (ACLARACIONES)}

Existen varias acepciones comunes sobre el término de satisfacción, sin embargo, para el diseño industrial la acepción de mayor importancia es aquella que tiene que ver con el gusto o agrado que provoca el uso de un producto o un servicio que cumple con las expectativas que tiene en relación con el mismo.

\section{SINÓNIMOS}

Calidad, gusto, complacencia, gozo, deleite, agrado, dicha, bienestar, regodeo, alborozo, alegria, reparación, indemnización, desagravio, compensación, arreglo, resarcimiento, reintegro, devolución, reembolso, recompensa, retribución, disculpa, excusa, descargo, presunción, vanidad, orgullo, respuesta, contestación, explicación, aclaración, solución.

\section{ANTÓNIMOS}

Desagrado, disgusto, descontento, tristeza, humildad, agravio.

\section{EJEMPLOS}

La calidad de servicio y la satisfacción de los usuarios es una de las principales áreas de estudio del comportamiento de los consumidores y usuarios, dado que el rendimiento de las empresas y organizaciones es valorado por las propias personas que adquieren y/o utilizan estos bienes de consumoy/o servicios, por ello los estudios de la calidad del servicio y de la satisfacción de los consumidores y usuarios, tienen en común la importancia del punto de vista de los clientes al valorar el producto y el servicio que proporcionan.
Sin embargo, los problemas complejos de diseño se caracterizan por poseer un gran número de variables en interacción, además de incógnitas. Al trabajar con este tipo de problemas, la satisfacción parcial reconoce que la combinación de complejidad e incógnitas hace poco probable (si no imposible) una solución óptima. Por lo tanto, la satisfacción parcial busca una solución satisfactoria que sea mejor que las alternativas existentes, es decir, pretende mejorar el diseño en lugar de lograr el mejor diseño posible. La satisfacción parcial deberá sopesar esta percepción del valor relativo en el desarrollo de las especificaciones de diseño, asegurando que las especificaciones óptimas no consuman los recursos de diseño, a menos que éstas sean decisivas para lograr el éxito y aumentar el valor concedido por los usuarios.

Por ejemplo, los diseñadores de Swatch se dieron cuenta de que los relojes de mayor precisión ya no eran valorados por los consumidores. Este estándar de "suficiencia" permitió a los diseñadores concentrar sus esfuerzos en la reducción de costos y aumentar las características estéticas, en lugar de intentar optimizar la precisión horaria de sus relojes.

\section{Sintesis formal o configurativa}

\section{DEFinición DicCionaRio RAE (DENOTACIÓN)}

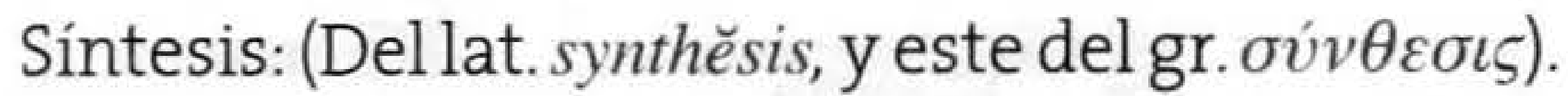
Composición de un todo por la reunión de sus partes. Suma y compendio de una materia u otra cosa. 
Formal: (Del lat.formālis). Perteneciente o relativo a la forma, por contraposición a esencia. Configuración: (Del lat. configuratĭo, -ōnis). Conjunto de rasgos que configuran o dan a una cosa el aspecto o la estructura que la caracterizan y la hacen como es. Disposición de las partes que componen una cosa y le dan su peculiar forma y propiedades adyacentes. Los aspectos configurativos son los que hacen que la forma sea percibida táctil y visualmente y comuniquen su función operativa. Para esto se aplican criterios de comunicación de los productos, como la Semiótica de los tableros de control.

\section{DESARROLLO O CONSTRUCCIÓN DEL CONCEPTO}

La síntesis es la acción a través de la cual el diseñador modifica y configura la forma de los productos. Este acto complejo involucra la concurrencia del pensamiento analítico y el pensamiento creativo. El pensamiento analítico facilita la estructuración del problema de diseño. El proceso creativo permite desarrollar, evaluar y seleccionar ideas para concebir de diferentes maneras la forma.

La palabra sintesis alude al proceso de reunir y ajustar partes o conceptos aislados para producir un todo integrado. El paso a la sintesis se inicia formalmente después que el problema ha sido bien comprendido, cuando algunas nociones sobre posibles soluciones se han sugerido durante los pasos procedentes. El punto que se tiene que resaltar es engañosamente obvio; no conviene empezar a concentrarse en las posibles soluciones hasta que la situación problemática se haya estudiado e identificado, y se haya establecido una formulación del problema razonablemente satisfactoria. Más que en ningún otro momento del proceso de diseño, la dificultad que exhibe la sintesis y configuración radica en su propósito: innovar. Más que ningún otro paso requiere de una actitud convergente, un talento especial para descubrir combinaciones de principios, de materiales o componentes, especialmente apropiados para solucionar el problema. Siempre habrá más de una solución para un problema y los diseñadores buscan tantas como puedan dentro del límite de tiempo de que disponen. Una solución es en realidad una sintesis de elementos componentes, que vence los obstáculos que entorpecen el camino y que, sin exceder los recursos disponibles ni rebasar los límites establecidos por las restricciones, logra las metas propuestas.

El proceso proyectual en la creación de un producto, define diversas etapas de sintesis de información, de datos que encuentran convergencia en un punto y ayudan a esclarecer lo necesario para desarrollar la siguiente fase, y así avanzar en las diferentes etapas de desarrollo, sin embargo, dicho proceso llega a un punto en donde la sintesis de datos debe dar un salto que nos permita obtener resultados más evidentes en términos formales.

Se requiere dotar a la solución proyectada de atributos formales indispensables para dar solución a las distintas variables que se encuentran en juego en la configuración formal de una solución de diseño.

La sintesis formal puede definirse como la búsqueda en la obtención de unidad y de coherencia en aspectos de forma. La coherencia es el 
resultado, entre otras cosas, de la interacción de los elementos que la integran. La búsqueda de la coherencia formal se realiza con códigos no discursivos, es decir, con esbozos, con modelos de máximas o con modelos particularizados.

El diseñador industrial conoce procedimientos gracias a los cuales puede reducir la gran variedad de las soluciones intermedias posibles, de tal modo que las indagaciones se lleven a cabo en un tiempo útil. La coherencia formal puede representar el resultado de encontrar maneras más eficientes y cortas para otorgar atributos de forma a las soluciones de diseño.

Es obvio que la coherencia formal se manifiesta como concordancia y compatibilidad entre varios elementos formales; concordancia y compatibilidad que contribuyen a hacer una unidad, tanto si se trata de un producto como de un sistema de productos. Hablar de coherencia formal también es hablar de relaciones entre diferentes elementos geométricamente descriptibles. De otorgar distintas jerarquías en la configuración externa e interna de un producto.

Un proyecto de diseño se presenta como una unidad funcional en la que es difícil separar los distintos elementos y momentos de composición a los que ha sido necesario recurrir y que ha sido indispensable recorrer antes de llegar a lo que bien podríamos denominar, de acuerdo a la expresión de Alexander (1975) "síntesis de la forma". La forma acaba siendo una y difícilmente desagregable, pues se ha sintetizado un todo, una estructura, un complejo. Pero ninguna forma nacida de la inteligencia humana y menos todavía las formas y modelos que se han desarrollado a partir de la Revolución Industrial, han escapado a una génesis y a un desarrollo en el que hacen su aparición todos los factores que ya se han mencionado en este trabajo.

\section{USOS O ACEPCIONES (ACLARACIONES)}

En la antigüedad se describía vagamente a la síntesis como un "salto al vacío", "una acto de equilibrista" o como el "vértigo de enfrentar la hoja en blanco". Sin más, explicaba esos actos conectados intimamente con lo creativo y, en esa omisión, la inspiración o el talento individual irrumpían como un acto prodigioso, similar a las ciencias renacentistas que admitían el poder de las artes mágicas.

Hoy, si bien se reconoce que es complejo, se indaga más en ello y las estrategias se transparentan, sustentadas en la concurrencia del pensamiento creativo vinculado con la intuición y el azar, pero también con el pensamiento analítico o lógico más cercano a la razón.

\section{SiNóNIMOS}

Sintesis: resumen, compendio, extracto, sumario, sinopsis, simplificación, acortamiento, disminución, reducción, epítome, condensación, recopilación, compilación, digesto, balance, bosquejo, guión, suma, argumento, epílogo, reunión, integración, constitución, elaboración, composición, creación, producción.

Formal: cumplidor, sensato, serio, responsable, educado, juicioso, prudente, consecuente, referente a la forma.

Configuración: forma, figura, conformación, estructura, ordenación, distribución, composición, clasificación 


\section{ANTÓNIMOS}

Sintesis: desarrollo, antítesis, análisis.

Formal: frívolo, informal, irresponsable.

Lo opuesto a la sintesis formal es la incoherencia formal, que se refiere a la falta de una relación coherente entre los elementos que componen un objeto.

\section{EJEMPLOS}

Para comprender de mejor manera estas "relaciones" formales que se dan en los objetos, deben entenderse como sistemas cuya relevancia y análisis entre elementos iguales o similares entran en el ámbito de la teoría de la simetría. Sin embargo, no debe la búsqueda de coherencia limitarse o centrarse en aspectos geométricos, sino por el contrario abarcar dimensiones preceptuales relacionadas con textura y color.

\section{Técnica, estrategia y pensamiento estratégico}

\section{Definición Diccionario RAE (DENOTACIÓN)}

Técnica (Del lat. technǐcus, y éste del gr. $\tau \varepsilon \chi v \iota x o ́ s$, de $\tau \dot{\varepsilon} \chi \nu \eta$, arte). Perteneciente o relativo a las aplicaciones de las ciencias y las artes. Conjunto de procedimientos y recursos de que se sirve una ciencia o un arte. Habilidad para ejecutar cualquier cosa, o para conseguir algo. Conjunto de los procedimientos que se siguen para elaborar un objeto complejo o para manejar alguna cosa, y habilidad que tiene una persona para hacerlo.

Estrategia (Del lat. strategı̆a, y éste del gr.

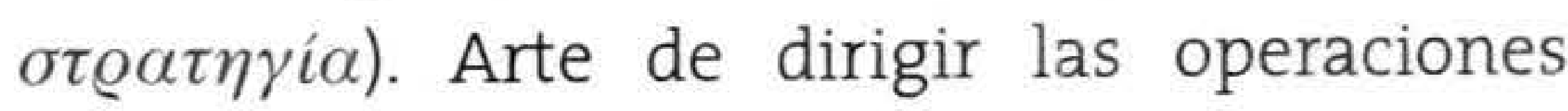

militares. Arte, traza para dirigir un asunto. En un proceso regulable, conjunto de las reglas que aseguran una decisión óptima en cada momento. Conjunto de medidas, acciones o procedimientos planeados y organizados cuidadosamente que sirven para llevar a cabo un propósito o alcanzar un fin determinado.

\section{DESARRollo o Construcción del CONCEPTO}

La estrategia es el plan general de acción para alcanzar un objetivo. La estrategia nos garantiza que tenemos claro el lugar hacia dónde vamos y cómo pretendemos llegar ahí. Es la manera cómo se enfrentará al proyecto de diseño, es decir, son los lineamientos generales para alcanzar el objetivo.

Formular una estrategia requiere conocer a profundidad todos los elementos que estarán presentes a la hora de desarrollar el proyecto de diseño, conocer los riesgos, las fortalezas, los recursos materiales y humanos con los que se cuenta, las diferentes técnicas, etc., es decir, tener una visión amplia del proyecto y el contexto para designar los lineamientos generales del plan de acción.

Es imprescindible a la hora de generar una estrategia tener una visión sistémica y holística de la problemática a abordar. Por lo tanto, la estrategia no surge en lo individual, sino que es un trabajo colegiado y en equipo que permite integrar la mayor cantidad de elementos del contexto desde diferentes perspectivas y análisis.

En el proceso de diseño, las técnicas hacen referencia a esos modos de hacer o desarrollar alguna parte específica del método. Por 
ejemplo, en la fase de ideación el brainstorming es una técnica grupal adecuada para generar más ideas y construir sobre las ideas de otros, funciona con ciertas reglas y es muy productiva ya que a medida que se avanza en el desarrollo, la calidad de las ideas es mayor, generando nuevas conexiones y posibilidades para la resolución del problema de diseño.

Si continuamos en esta línea con la definición de estrategia, las técnicas se pueden homologar a las tácticas, es decir, las tácticas son las acciones concretas que se siguen para alcanzar el objetivo general.

El pensamiento estratégico es ese proceso que nos lleva a formular las estrategias, nos hace ver los problemas o problemáticas desde diferentes puntos de vista que nos permiten generar diferentes planes de acción para conformar escenarios posibles (en prospectiva "futuribles") los cuales nos sirven para llevar adelante los diferentes planes para alcanzar los objetivos del proyecto.

El pensamiento estratégico apela a un método específico que ayuda a abordar los contextos y problemáticas de una manera diferente y permite llegar a múltiples soluciones como estrategias de innovación.

\section{USOS O ACEPCIONES (ACLARACIONES)}

Hablar de estrategia en el diseño se ha convertido en un término de moda, sin embargo, toma sentido cuando nos metemos en el ámbito de la competitividad, donde sobrevivir con una empresa o producto se convierte en una guerra (estrategia), y para ganar esa guerra debes emplear diferentes armas (tácticas).
En cuanto a estrategia, actualmente el diseño asume dos posturas claras: la primera hace referencia al diseño como una estrategia que ayuda a la empresa en la competitividad. La segunda postura es la de una disciplina que se encarga de generar estrategias (diseño estratégico).

\section{SinónIMOS}

Estrategia: maniobra, habilidad, pericia.

Técnica: método, procedimiento, sistema, capacidad, destreza, habilidad, experiencia, arte, ciencia, habilidad, práctica, proceso, recurso, sistema.

Táctica: método, procedimiento, sistema, plan.

\section{ANTónimos}

Estrategia: impericia, improvisación.

Técnica: intuición, ocurrencia, improvisación.

\section{EJEMPLOS}

En diseño, una estrategia debe considerar hacia dónde vamos y por qué. Por ello es importante visualizar los futuros posibles (hacer prospectiva) para así designar el plan general a seguir. Para generar estos escenarios es posible utilizar la técnica de exploración de escenarios (Rodríguez, 2004:115).

Fijar la temporalidad:

- En cuánto tiempo queremos visualizar el escenario.

- Establecer el objetivo del análisis a realizar.

- Identificar características dominantes: son las que permanecen en el tiempo (valores, paradigmas, etc.).

- Identificar fuerzas directrices: que orientan 
o dirigen las tendencias (políticas gubernamentales, estilos).

- Identificar tendencias (elementos que están en constante cambio: modas, vanguardias, etc.).

- A partir de la identificación de características dominantes, fuerzas directrices y tendencias, buscar dos variables que se puedan plantear como polos opuestos para que en el cruce de estas variables se puedan generar cuatro escenarios posibles.

- Se analizan los cuatro escenarios posibles, llegando a una descripción de cada uno de ellos.

- Se evalúan los cuatroy se decide cuál es el más probable y cuál el deseable. A partir de esto se proponen acciones para enfrentar dichos escenarios y proponer estrategias pertinentes, usando el análisis de fortalezas, oportunidades, debilidades y amenazas (FODA).

\section{Uso, usuario, usabilidad}

\section{Definición Diccionario RAE (DENOTACIÓN)}

Uso. Del lat. Usus. Acción o efecto de usar. Hacer servir una cosa para cierto fin. Ejercicio o práctica general de una cosa. Funcionamiento o manera de utilizar una cosa, especialmente un aparato o máquina. Modo determinado de obrar que tiene una persona o cosa.

Usuario. Persona que usa una cosa o servicio y se sirve habitualmente de ella.

Usabilidad: Es un anglicismo que significa "facilidad de uso" y parece tener su origen en la expresión user friendly. Se refiere al grado de eficacia, eficiencia y satisfacción con la que los usuarios especíicos pueden lograr metas y objetivos definidos en contextos de uso determinados de antemano.

El uso está vinculado a la utilización que una persona hace de un objeto, aparato o máquina para obtener un servicio o alcanzar una meta. También puede hacer referencia a la utilización de algo simbólico o inmaterial, o bien al hábito o costumbre que se reitera con cierta frecuencia.

\section{DESARROLLO O CONSTRUCCIÓN DEL CONCEPTO}

Los objetos se organizan en distintos tipos de artefactos con valores funcionales determinados por la utilidad que proporcionan al usuario. En la actualidad este es el factor condicionante de la producción industrial que, sin embargo, parte de una concepción abstracta del usuario al cual es destinada. Hoy en día los objetos de uso cotidiano fabricados en masa, responden a criterios utilitarios y estéticos que con frecuencia nada tienen que ver con las necesidades y gustos del usuario-consumidor. Por lo tanto, la sintesis formal se da en atención a un receptor abstracto, único y universal, arquetipo concebido en la mente del diseñador que parte de los requerimientos condicionados por quienes inducen, persuaden o hacen necesario algo y no por quienes efectivamente lo necesitan.

El usuario es el objeto y fin de toda acción de diseño, con la salvedad de que éste se relaciona con el proyecto a través de las necesidades tipificadas en un grupo de usuarios de características similares y no a través de una intervención directa en las decisiones. El diseñador ha quedado así separado del demandante real, haciendo indispensable 
rescatar la relación diseñador-usuario. Algunos teóricos sugieren la posibilidad de un diseño abierto participativo en que patrocinadores, diseñadores y usuarios integren un proceso que permitan diseños mejor adaptados a las necesidades físicas y espirituales de estos últimos.

La importancia del diseño de los objetos, aparatos o máquinas se basa en que el primero (diseño) será el que modele la interacción entre el usuario y, los segundos (objetos) posibilitarán o no el uso y la consecución de los objetivos perseguidos por el diseñador. Es sencillo inferir que un buen diseño deberá ser fácil de usar, comprensible, amigable, claro y de fácil aprendizaje. Para asegurar que un buen diseño cumple con estos requisitos no basta simplemente con la actitud intuitiva del diseñador, es imprescindible la adopción por parte de éste de técnicas, procedimientos y métodos que aseguren empíricamente la adecuación del diseño a las necesidades, habilidades y objetivos de los usuarios. Se suele hablar del Diseño de la Usabilidad como el conjunto de fundamentos teóricos y metodológicos que aseguren el cumplimiento de los niveles de usabilidad requeridos para el buen diseño de objetos, aparatos y máquinas.

El modelo conceptual de la usabilidad, proveniente del diseño centrado en el usuario, no está completo sin la idea de utilidad (concepto tan obvio que ni siquiera debería ser objeto de discusión). Esta definición hace énfasis en los atributos internos y externos del producto, los cuales contribuyen a su funcionalidad y eficiencia. La usabilidad depende no sólo del producto sino también del usuario. Por ello un producto no es en ningún caso intrínsecamente usable, sólo tendrá la capacidad de ser usado en un contexto particular y por usuarios particulares, entonces, la usabilidad está más relacionada con la ergonomía y los factores humanos.

\section{USOS O ACEPCIONES (ACLARACIONES)}

Un concepto intimamente ligado al de usabilidad es el de accesibilidad. Éste no se refiere a la facilidad de uso, sino a la posibilidad de acceso del usuario a los beneficios de estos productos. El diseño como requisito indispensable para ser usado habrá de posibilitar el acceso a todos los potenciales usuarios, sin excluir aquellos con limitaciones individuales o limitaciones propias del contexto. Se da la paradoja de que mientras un diseño requiere limitar su campo de acción, el diseño accesible implica diseñar la diversidad y la heterogeneidad de necesidades de acceso presentados por usuarios diversos.

Tanto los objetos como los espacios deben diseñarse de manera que puedan ser utilizados, sin necesidad de modificación alguna, por el mayor número de personas. Construir un ambiente accesible para todos. Este "todos" incluye a una parte importante de la sociedad: las personas con alguna discapacidad, y de otros sectores de la población: mujeres embarazadas, analfabetas, débiles visuales con bastón o perro lazarillo, personas que padecen alguna incapacidad permanente o temporal, física o intelectual, adultos mayores que utilizan muletas o andadores, etc., que requieren hacer uso de los espacios urbanos, áreas de resguardo, señalamientos y objetos. Significa eliminar 
obstáculos del entorno físico para facilitar el acceso y uso de espacios y objetos a todos los usuarios. El principio de accesibilidad afirma que los diseños deben ser utilizables, sin adaptaciones o modificaciones especiales por parte de personas con diferentes capacidades.

La accesibilidad en el campo del diseño se ha centrado, históricamente, en las personas con discapacidades, pero a medida que van aumentando los conocimientos y la experiencia sobre diseño accesible, se hizo patente que muchas adaptaciones necesarias se podían diseñar de manera que beneficiasen a todo el mundo. Los diseños accesibles presentan cuatro características: acrecientan la percepción, facilitan la operatividad, eliminan la complejidad y amplían el nivel de tolerancia. El diseñador puede desempeñar un papel crucial para que la tecnología sea accesible a las necesidades del hombre. Toda la tecnología, si carece de esta interfase esencial, sólo es una fuente de frustración y enajenación.

El diseñador debe ser una especie de ombudsman que en el equipo multidisciplinario de diseño propugne la defensa del usuario ante la creciente tecnicidad de los objetos que rodean al hombre. Esta responsabilidad moral y global de lo que genera una sociedad tecnificada no la asume nadie en el complejo circuito creativo, por ello, existe la necesidad de que alguien vele para que los frutos resultantes de todo ese saber hacer no se hagan en detrimento de la humanidad y de su bienestar, propósito y fin de todo el saber humano. El diseñador no puede limitarse a resolver sin más una ecuación basada en puras exigencias técnicas o de mercado, ni ser un mero maquillador de las mercaderías que la sociedad industrial tan fácilmente promueve. Ha de entender esa misión como algo más que un acto estético y sentir su responsabilidad en el devenir de lo que la sociedad crea.

\section{SINÓNIMOS}

Uso: utilización, adjudicación, beneficio, empleo, legación, usufructo, manejo, usanza, hábito, práctica, costumbre, estilo.

Usuario: consumidor, cliente, adjudicatario, legatario, favorecido, usufructuario, agraciado, beneficiario.

\section{ANTÓNIMOS}

Uso: desuso, inutilidad.

\section{Valor}

\section{Definición Diccionario RAE (DENOTACIÓN)}

El valor es la calidad y la cualidad que constituye una cosa digna de estimación o aprecio. Utilidad o aptitud que tienen los bienes para satisfacer necesidades humanas. Se desprende del vocablo latín estimable que le da su significación etimológica. Su interpretación filosófica se resume en la utilización del término axiología (del griego axia, valor y logos, estudio).

Los valores son convicciones profundas de los seres humanos que determinan su manera de ser y orientan su conducta. Los valores involucran nuestros sentimientos y emociones. Para Platón valor era "lo que da la verdad a los 
objetos cognoscibles, la luz y belleza a las cosas, etc., en una palabra es la fuente de todo ser en el hombre y fuera de él". Existe una concepción subjetiva de los valores. Lo que de algún modo es objeto de apetito o deseo humano es lo que se llama bueno. Y el objeto de su odio y aversión, malo; y de su desprecio, lo vil y lo indigno. Pero estas palabras de bueno, malo y despreciable siempre se usan en relación con la persona y su escala de valores. Expresa el significado externo de los objetos para el hombre y desde este punto de vista los valores se fetichizan o se reducen a propiedades naturales.

\section{DESARROLLO O CONSTRUCCIÓN DEL CONCEPTO}

El valor es un término que se usa a menudo en el campo del diseño. La función del diseño es la de crear valor. El valor puede tener varios sentidos, muy distintos entre ellos. Cuando se habla de valor en diseño se hace referencia principalmente al valor comercial o de la productividad, pero también deberíamos incluir bajo ese término valores sociales, culturales, ambientales, políticos y simbólicos. No se limita a la noción de equiparar "buen diseño" con valor, sino que alude a la creación de nuevos productos y formas, y también al incremento del valor. Los diseños pueden añadir valor directamente al aumentar las ventas, reducir costos de producción y/o al incrementar el prestigio de la marca o la organización. Sin embargo, es difícil saber las razones reales del éxito puesto que hay muchas variables implicadas.

El diseño es una aptitud básica, una actividad económica fundamental; es un factor intrínseco a la industria y las empresas, no sólo como parte del proceso de innovación y creación de imágenes y productos, sino también como una forma de pensamiento sobre "experiencias vitales". La creación de experiencias y su impacto sobre el comportamiento humano y el mundo, ya sea material o inmaterial, constituyen el ámbito del diseño. Dentro del contexto de planteamiento del problema nos interesa el valor que el cliente o el organismo promotor del diseño considera pertinente para el producto a diseñar. Esto es muy difícil de medir y de evaluar, pero el diseño puede ser una contribución muy valiosa para estas instancias si encaja bien con los valores del usuario-consumidor al que está dirigido el producto-mercancía. El planteamiento del problema de diseño tiene que centrarse en la producción de una solución que se comunique positivamente con este público.

Los valores surgen en la relación práctico-objetual y no en el simple conocimiento de las cosas por el hombre. Son el resultado de la actividad práctica del hombre. De tal forma los valores no existen fuera de las relaciones sociales, de la sociedad y el hombre. El valor es un concepto que, por un lado, expresa las necesidades cambiantes del hombre y, por otro, fija la significación positiva de los fenómenos naturales y sociales para la existencia y desarrollo de la sociedad. Reservamos la afirmación del valor como propia únicamente de las cosas cuya utilidad se nos ofrece en toda la plenitud de su desarrollo, merced a la acción ejercida sobre ellas por el trabajo.

Los valores son una cualidad sui géneris de un objeto. Los valores son el sustento de las características físicas, tangibles del objeto; es 
decir, son atribuidos al objeto por un individuo o un grupo social, modificando - a partir de esa atribución - su comportamiento y actitudes hacia el objeto en cuestión. Se puede decir que la existencia de un valor es el resultado de la interpretación que hace el sujeto de la utilidad, deseo, importancia, interés y belleza del objeto. Es decir, la valía del objeto es, en cierta medida, atribuida por el sujeto, de acuerdo a sus propios criterios e interpretación, producto de un aprendizaje, de una experiencia, la existencia de un ideal, e incluso de la noción de un orden natural que trasciende al sujeto en todo su ámbito.

Los valores son creencias o convicciones de que algo es preferible y digno de aprecio, éstos se jerarquizan por criterios de importancia. Cada persona construye su escala de valores personales. Esto quiere decir que las personas preferimos unos valores a otros. Los valores más importantes de la persona forman parte de su identidad. Orientan sus decisiones frente a sus deseos e impulsos y fortalecen su sentido del deber ser. Los valores se aprenden desde la temprana infancia y cada persona les asigna un sentido propio, de acuerdo a sus experiencias, conocimientos previos y desarrollo cognitivo, cada individuo construye un sentido propio de los valores; éstos y su jerarquización pueden cambian a lo largo de la vida, están relacionados con los intereses y necesidades de las personas a lo largo de su desarrollo.

El análisis del valor es una técnica de análisis crítico de la relación utilidad-costo similar enfocado al procedimiento que aplican los diseñadores. Comparado con el sistema habitual de disminución de costos - sustitución de componentes por otros más baratos, sin alteración del producto como tal-, el análisis del valor se diferencia porque pone en tela de juicio la estructura del producto, es decir, no considera dicha estructura como inalterable. Cada componente se valora de acuerdo a la función que realiza y a lo que cuesta ésta. Ello implica considerar al producto como un conglomerado de proveedores de utilidad, cada uno de los cuales tiene su costo en dinero, estos costos pueden compararse a las funciones, y se intenta elevar la utilidad al máximo y disminuir el costo relativo al mínimo. Dado que el análisis del valor es interdisciplinario, el diseñador, cuyas actividades son también interdisciplinarias, no debe encontrar dificultades para acomodarse a este procedimiento.

\section{USOS O ACEPCIONES (ACLARACIONES)}

Valores, actitudes y conducta están relacionados. Una actitud es una disposición a actuar de acuerdo a determinadas creencias, sentimientos y valores. A su vez las actitudes se expresan en comportamientos y opiniones que se manifiestan de manera espontánea.

El producto como mercancía se descompone en dos categorías opuestas: valor de cambio y valor de uso. Mientras que en el marco de las leyes férreas del mercado, la racionalidad del productor persigue la maximización del valor de cambio, la racionalización del consumidor busca la minimización del mismo; y con signo opuesto, rige la misma dualidad respecto al valor de uso. El valor de uso de un objeto 
equivaldría a su valor funcional.

El objeto primitivo era adecuado a una necesidad de uso y nada más. Todo era más "sencillo": la naturaleza marcaba el ritmo de la contingencia y el hombre respondía, después de haber experimentado la necesidad, con los medios que la propia naturaleza le ofrecía. Parece demostrable que, por lo menos en el estadio fundacional de los objetos, éstos no tuvieron ningún valor de cambio (no en el sentido que hoy lo conocemos).

El valor de uso se puede dividir a su vez en valores de uso físico y valores de uso psíquico. Los valores de uso físico se refieren a los valores operativos, como diversas aptitudes de las formas materiales para generar hechos de naturaleza física correlacionada con su valor de utilización y funcionamiento. Tiene que ver con la relación entre el hombre y el objeto: el confort, la seguridad y el mantenimiento. También tiene que ver con su compatibilidad con otros productos. Los valores de uso psíquico se refieren a valores estéticos de tipo perceptivo, informativo y de expresión.

El valor de signo sería aquel incorporado a un objeto, por el cual dicho objeto pasa a tener un valor de significación, de un orden distinto al valor de uso, aunque no menos "funcional" que éste. Casi todos los objetos industriales contienen algunas cualidades formales que simbolizan su función denominado como valor de signo o simbólico, aptos para hacer que el objeto resulte más fácilmente identificable. La mayoria de las veces la función tiene que ser recalcada y exaltada de tal manera que produzca una inmediata impresión del objetivo para que el objeto fue creado. Puede ocurrir que la función sea, por un lado, exaltada y acentuada, mientras que al mismo tiempo se oculta y se "enmascara" la parte mecánica del artefacto (como sucede en casi todos los objetos que tienen carrocería). La razón de este enmascaramiento o disfraz está en el hecho de que los mecanismos tienen que estar ocultos para protección del usuario.

La fase consumista del diseño se caracteriza, entre otras cosas, por el hecho de que sus producciones, además de estar dotadas de poca 0 mucha utilidad, tienen incorporado en su propia contextura un peculiar valor de cambio-signo que llega a ser determinante para el diseño.

\section{SiNónIMOS}

Valía, cuantía, monto, evaluación, tasación, valoración

\section{ANTÓNIMO}

No existe.

\section{EJEMPLOS}

El quehacer del diseño es una actividad sujeta a factores económicos y por ello responde a las leyes de producción, distribución y consumo. Desde el momento en que los objetos de diseño satisfacen necesidades reales $\mathrm{o}$ aparentes de usuarios condicionados socialmente, adquieren un carácter de mercancías. El poseedor de una mercancía (vendedor) se sitúa respecto a ésta en la posición del valor de cambio; quién no la posee (comprador), por el contrario, en la posición del valor de uso. Para su poseedor la mercancía 
vale únicamente como medio de cambio, le interesa, en consecuencia, bajo el punto de vista cuantitativo, por cuanto quiere obtener por ella lo más posible. Para quien no la posee, la mercancía sirve de subsistencia (en el sentido amplio con que utilizamos esa palabra); le interesa, por consiguiente, en primer lugar bajo el punto de vista cualitativo de su utilidad para satisfacer necesidades (y dependiendo de esta utilidad, también, por supuesto, cuantitativamente).

Sin embargo, no es el valor de uso real, sino la promesa del mismo lo que desencadena la compra. Todo el mundo sabe por experiencia diaria que lo exterior de la mercancía, su apariencia, su aspecto fenoménico - tal vez las propiedades de la superficie que pueden tocarse con los dedos, quizás el olor, juntamente con la marca, la calidad y cantidad, etc.-, "promete" al comprador el valor de uso. Dicho con exactitud, él mismo se crea las expectativas basándose en las evidencias que la forma del objeto dicta a sus sentidos. A esa relación causal compleja Wolfgang Fritz Haug (1989) la denomina como "la promesa estética del valor de uso" de la mercancía. Entiende "lo estético de la mercancía" en razón de "lo sensible de una cosa que nos muestra su sentido". Es precisamente esas evidencias físicas las que el diseño se encarga de crear. El origen de los primeros centros de enseñanza de "técnicas estéticas" obedeció a la presión de la demanda de especialistas en la configuración estética de las mercancías, resultante del desarrollo de la manufactura y la industria.

Llevar a cabo dinámicas con grupos focales puede ser una indicación de la aceptación real del producto en un segmento del mercado. Éstas se tienen que llevar a cabo con un prototipo, modelo o simulador virtual que aproxime lo más cerca de la realidad: la relación hombre-objeto. 


\section{Bibliografía}

ADORNO, Theodor W. (2004), Teoría estética, Madrid: Ediciones Akal, pp. 67, 109, 129, 133, 152, 279, 455.

AICHER, Otl (1994). Analógico y digital, Barcelona: Gustavo Gili, p. 255.

AleXander, Christopher (1975), Comunidad y privacidad. Hacia una nueva arquitectura humanista, Buenos Aires. p. 151. (1973), Ensayo sobre la sintesis de la forma, Buenos Aires, Ediciones Infinito, pp. 51, 59. Alger, John R. M., Hayes, Carl V. (1966), Sintesis creadora en el diseño, México: Herrero Hnos. Sucs., pp. 7, 36, 37, 40, 43, 59.

AMBRose, Gavin y Harris, Paul (2010), Metodología del diseño. El acto o la práctica de usar tu mente para considerar el diseño, Barcelona: Parramon, p. 66,70 .

ARAmbula Ponte, Paolo (2010), Diseño, emoción y complejidad, México: Tesis Posgrado en Diseño Industrial/ UNAM, p. 49, 101, 106.

Asimow, Morris (1976), Introducción al proyecto, México: Herrero Hnos, pp. 28, 36, 37, 42, 44, 52, 68, $72,73,74,77,79,82,85,88,96,146,149,159,160$, $171,178$.

BANHAM, Peter Reyner (1985), Teoría y diseño en la primera era de la máquina, Buenos Aires: Ed. Paidós, p. 37.

BAUDRILLARD, Jean (1976), Crítica a la economía política del signo, México: Ed. Siglo XXI, pp. 121, 133, 148, 251.

(1969), El sistema de los objetos, México: Ed. Siglo XXI, , pp. 84, 125, 141, 146.

BITNER, M. J. (1990), “Evaluating Service encounters: The effects of physical surroundings and Employee responses", Journal of Marketing, pp. 54, 69-82.
Bloemer, J. y de Ruyter, K. (1995), "Integrating service quality and satisfaction: pain in the neck of marketing opportunitys", Journal of Consumer Satisfaction, Dissatisfaction and Complaining Behaviour, 8, pp. 44-52.

Bloemer, M. M. y Polesz, B. C. (1989), "The illusion of consumer satisfaction", Journal of Consumer Satisfaction, Dissatisfaction and Complaining Behaviour, 2, pp. 43-48.

Bohigas, Oriol (1978), Proceso y erótica del diseño, Barcelona: La gaya ciencia, p. 26, 45, 47, 53, 96, 139 , 163, 165, 187, 195, 198, 233, 261, 266.

BONSIEPE, Gui (1998), Del objeto a la interfase. Mutaciones del diseño, Buenos Aires: Ediciones Infinito, p. 61. - (1985), El diseño de la Periferia. Debates y experiencias, México: Gustavo Gili, p. 27. (1978) Diseño industrial, tecnología y dependencia, México: Ed. Edicol, pp. 22, 28, 32, 36, $43,45,51,105,112,115,119,120,121,122,126,127$. - (1978), Teoría y práctica del diseño industrial. Elementos para una manualística crítica, Barcelona: GG, pp. 65, 148, 149, 151, 153, 160. BROADBENT, Geoffrey (1976), Diseño arquitectónico. Arquitectura y ciencias humanas. Barcelona: Gustavo Gili, p. 120, 175, 245, 263, 322, 367.

BÜRDECK, Bernhard E. (1994), Diseño. Historia, teoria y práctica del diseño industrial, Barcelona: G. Gili, p. 15, 122, 156, 157, 161, 171, 175, 185, 281, 279.

CAMPI Valls, Isabel (2005), La idea y la materia. Vol. 1: El diseño de producto en sus orígenes, Barcelona: Gustavo Gili, p. 229.

CHAVES, Norberto (2003). La marca corporativa, gestión y diseño de símbolos y logotipos, México: Ed. Paidós, p. 113. 
(2002), El oficio de diseñar. Propuesta a la conciencia critica de los que comienzan, Ed. Gustavo Gili, Barcelona.

(2001), La imagen corporativa. Teoria y

metodología de la identificación institucional,

Barcelona: Gustavo Gili, p. 107, 108, 116, 152, 153 . 154, 158.

CHIAPPONI, Medardo (1999), Cultura social del producto. Nuevas fronteras para el diseño industrial, Buenos Aires: Ediciones Infinito, p. 111. CostA, Joan (2003), Imagen corporativa en el siglo XXI, Buenos Aires: La Crujía, pp. 97, 145, 169, 248.

CROss, Nigel (1999), Métodos de diseño. Estrategias para el diseño de productos, México: Ed. Limusa, Noriega Editores, pp. 20, 29, 43, 47, 54, 60, 76, 88, $102,115,116,131,132,156,175,181,182$.

DABHOLKAR, A. D. y Thorpe, D. I. (1994), “Does customer satisfaction predict shoper intentions?", Journal of Consumer Satisfaction, Dissatisfaction and Complaining Behavior, 7, pp. 161-171.

De Fusco, Renato (2005) Historia del diseño, Barcelona: Santa \& Cole, p. 370.

DE VEGA, M. (1984), Introducción a la psicologia cognitiva. Madrid: Alianza Editorial.

Diseños Industriales. Guía del usuario (2008), División de Patentes, México: Instituto Mexicano de la Propiedad Industrial, Secretaría de Economía.

DORFLES, Gillo (1977), El diseño industrial y su estética. Barcelona: Ed. Labor (Nueva Colección Labor), p. 41, 45, 73, 85, 105. (1972), Naturaleza y artificio, Barcelona: Ed. Lumen, pp. 57, 60, 104, 124, 168, 171, 235. Droste, Magdalena (1991), Bauhaus. 1919-1933. Berlín: Ed. Benedickt Taschen, p. 53.
DUSSEL, Enrique (1984), Filosofia de la producción, Bogotá: Editorial Nueva América, pp. 49, 132, 189, 190, 192, 193, 194, 195, 196, 198, 200, 208, 209, 210, 212, 214, 224 .

_- et al., (1977), Contra un diseño dependiente: un modelo para la autodeterminación nacional, México: Ed. Edicol, pp. $37,129,281,305$

ELLIOTT, David (1980), Diseñando el futuro, Barcelona: Ed. Gustavo Gili, pp. 68, 41, 93. (1980), Diseño, tecnología y participación, Barcelona: Gustavo Gili, pp. 31, 32, 35, 55, 84, 93 , 126,153 .

ERLHOFF, Michael y Marshall, Tim (Editores) (2008), Design Dictionary. Perspectives of Design Terminology, Berlín: Board of International Research in Design, BIRD, pp. 70, 92, 236.

FORNARI, Tulio (1989), Las funciones de la forma, México: Ed. Tilde, pp. 9, 42, 54, 56, 58, 61, 77, 81, 91, 95, 97.

FRASCARA, Jorge (1997), Diseño gráfico para la gente. Comunicaciones de masa y cambio social, Buenos Aires: Ediciones Infinito, pp. 85, 90, 98, 104, 105, $128,136,137,143,146,180$.

FRONDIZI, Risieri (1992), ¿Qué son los valores?, México: Fondo de Cultura Económica.

FUAD-LUKE, Alastair (2002). Manual del diseño ecológico, Palma de Mallorca: Ed. Cartago, p. 327.

GARCíA, M. (2001), Metodología del Diseño Industrial, Ed. Editorial de la Universidad Politécnica de Valencia, p. 97.

GARDNER, Howard (1997), Arte, mente y cerebro. Una aproximación cognitiva a la creatividad, Barcelona: Paidós, p. 377 
GIESE, J. l. y Cote, J. A. (1999), Defining Consumer Satisfaction. Academy of Marketing Science Review, 1, pp. 1-34.

GILL, Bob (1982), Olvide todas las reglas que le hayan enseñado sobre el diseño gráfico. Incluso las de este libro, Barcelona: Gustavo Gili, p. 7.

GonZÁlez Ochoa, César (2007), El significado del diseño y la construcción del entorno, México: Designio, p. 181.

HAUG, Wolfgang Fritz (1989), Publicidad y consumo: critica de la estética de mercancías, México: Fondo de Cultura Económica, p. 23, 33, 46, 95, 102, 114, 130, 136, 145, 212, 233.

IRIGOYEN Castillo, Jaime F. (2008), Filosofia y diseño. Una aproximación epistemológica, México: UAM Xochimilco, p. 139.

IVÁÑEZ G., José María (2000), La gestión del Diseño en la empresa, Madrid: McGraw-Hill Interamericana, p. 17.

JONES, Christopher J. (1978), Métodos de diseño, Barcelona: Gustavo Gili, p. 3, 13, 39, 40, 43, 53, 59 , $67,81,85,87,96,120,132,149,151,171,180,187,192$, 212, 247, 249, 271, 312, 320, 329.

JulieR, Guy (2010), La cultura del diseño, Barcelona: Gustavo Gili, p. 15.

KeLLEY, Tom, Littman, Jonathan (2010), Las diez caras de la innovación. Estrategias para una creatividad excelente, Barcelona: Paidós Ibérica.

(2001), The Art of Innovation: Lessons in Creativity from IDEO, America's Leading Design Firm, Currency / Doubleday.

LeIRO, Reinaldo J. (2006), Diseño, estrategia y gestión, Buenos Aires: Ediciones Infinito, pp. 45 , 157,167 .
LIDWELL, William, Holden, Kitrina y Butler, Jill (2005), Principios universales de diseño, Barcelona: Ed. Blume, p. 54, 84, 122, 170.

LLOVET, Jordi (1979), Ideología y metodologia del diseño. Una introducción crítica a la teoría proyectual, Barcelona: Gustavo Gili, p. 26, 37, 53 , $54,55,72,123$.

LÖBACH, Bernd (1981), Diseño Industrial. Bases para la configuración de los productos industriales, Barcelona: Gustavo Gili, p. 137.

MALDONADO, Tomás (1977), Vanguardia y racionalidad, Artículos, ensayos y otros escritos, Barcelona: Gustavo Gili, pp. 125, 169.

MANZINI, Ezio (1996), Artefactos. Hacia una nueva ecologia del ambiente artificial, Celeste Ediciones, p. $37,42,135$. (1993), La materia de la invención. Materiales y proyectos, Barcelona: Ediciones CEAC, p. 23, 55, 79 .

MAÑA, Jordi (1973), El diseño industrial, Barcelona: Salvat Editores (Biblioteca Salvat. Grandes Temas), p. 108, 144.

Martínez-TuR, V., Peiró, J.M; y Ramos, J. (2001), Calidad de servicio y satisfacción del cliente: una perspectiva psicosocial, Madrid: Sintesis.

MASEDA Martín, Pilar (2006), Los inicios de la profesión del diseño en México, genealogía de sus incidentes, México: CONACULTA, p. 21.

Moles, Abraham (1983), Teoria de los actos. Hacia una ecología de las acciones, México: Trillas, p. 183. - (1975), Teoria de los objetos, Barcelona: Gustavo Gili, p. 47, 85, 127. - (1971). Los objetos, Buenos Aires: Tiempo Contemporáneo, p. 77, 201. 
MOSOQUERA, Gerardo (1989), El diseño se definió en octubre, La Habana: Editorial Arte y Literatura, p. 214 .

MUMFORD, Lewis (1982), Técnica y civilización, Madrid: Alianza Editorial, pp. 78, 128, 341. (1968), Arte y técnica, Buenos Aires: Ed. Nueva Visión, p. 136.

MUNARI, Bruno (1992), El arte como oficio, Barcelona: Editorial Labor, p. 123. (1983), ¿Cómo nacen los objetos? Apuntes para una metodología proyectual, Barcelona Gustavo Gili, pp. 9, 37, 104. (s/a), Diseño y comunicación visual, Barcelona: Gustavo Gili, pp. 11, 27, 352.

NORMAN, Donald A. (1998), La psicología de los objetos cotidianos, Ed. Nerea, p. 231.

OleA, Oscar y González L., Carlos (1988), Metodologia para el diseño, México: Ed. Trillas, pp. 69, 75, 77, 91-95.

Oliver, R. (1991), A guide to the Ordnance Survey one-inch Seventh, Series, 44.

OSBORN, Alex F. (1960), Imaginación aplicada. Principios y procedimientos para pensar creando, Madrid: Velflex.

PAPANEK, Victor (1977), Diseñar para un mundo real. Para una ecología humana y cambio social, Madrid: H. Blume Ediciones, pp. 19, 84.

Peterson, R.A. y Wilson, W.R. (1992), “Measuring customer satisfaction: fact and artefact", Journal of the Academy of Marketing Science, 58, pp. 111-124.

POTTER, Norman (1999), Qué es un diseñador: objetos lugares, mensajes, Barcelona: Ed. Paidós, pp. 77, 157.
PRESS, Mike y COOPER, Rachel (2009). El diseño como experiencia. El papel del diseño y los diseñadores en el siglo XXI, Barcelona Gustavo Gili, pp. 78, 115, 117, 118, 121, 124, 127, 136, 143, 151. QuARANTE, Danielle (1992), Diseño Industrial 1. Elementos teóricos, Barcelona: Ediciones CEAC, pp. 12. (1992), Diseño Industrial 2. Elementos teóricos, Barcelona: Ediciones CEAC, pp. 21, 25, 27. $37,45,59,73,86,91,97,105,144,164$.

READ, Herbert (1970), Arte y sociedad, Barcelona: Ed. Península, p. 152. (1961), Arte e industria. Principios de diseño industrial, Buenos Aires: Ed. Infinito, pp. $22,48,51$.

Ricard, André (2008). Conversando con estudiantes de diseño, Barcelona: Ed. Gustavo Gili, pp. 21, 47. (2000), La aventura creativa. Las raices del diseño, Barcelona: Ariel, p. 25, 41, 46, 79, 97 , $102,103,126,135,162,164,173,177,180$.

Rodríguez E., Mauro (1999), Manual de creatividad, México: Ed. Trillas, p. 87.

RODRÍGUez Morales, Gerardo (1986), Manual de diseño industrial. Curso básico, México: Gustavo Gili, pp. 31, 32.

RODRÍGUEZ Morales, Luis (2004), Diseño: estrategia y táctica, México: Siglo XXI, p. 79, 95, 119, 129, 149. (1989), Para una teoría del Diseño, México: Ed. Tilde UAM, pp. 19, 22, 23, 28, 43.

SAliNAS, Oscar (1992), Historia del diseño industrial, México: Ed. Trillas, p. 18

SCHÖN, Donald A. (1998), El profesional reflexivo: cómo piensan los profesionales cuando actúan, Barcelona: Paidós Ediciones, p. 31. 
- (1992), La formación de profesionales

reflexivos: hacia un nuevo diseño de la enseñanza

y el aprendizaje de las profesiones, Barcelona:

Paidos, pp. 53, 83, 115.

SELLE, Gert (1975), Ideologia y utopia del diseño, Barcelona: Gustavo Gili (Colección Comunicación Visual), pp. 33, 51, 201.

SiMóN Sol, Gabriel (2009), La trama del diseño. Porqué necesitamos métodos para diseñar. Designio Teoría y Práctica, México, p. 29, 77, 89, 93, 103, 113, 153 .

SIMON, Herbert A. (2006), Las ciencias de lo artificial, Barcelona: Editorial Comares, p. 126, 145, 170, 201, 217.

SIMONDON, Gilbert (2007). El modo de existencia de los objetos técnicos, Buenos Aires: Ed. Prometeo, p. $41,45,71,77,81,105,108,114,131,137,151,164$.

Solanas Donoso, Jesús V. (1981), Diseño, artey función, Barcelona: Salvat Editores, (Aula Abierta Salvat), p. 42, 56.

Sото, Carlos (2004), Desarrollo profesional del proyecto de diseño industrial, análisis de sus factores, Tesis de Maestría en Diseño Industrial, Teoria, Arquitectura, UNAM.

TAPIA, Alejandro (2004), El diseño gráfico en el espacio social, México: Ed. Designio, p. 17, 162.
TEAS, R. K. (1993), "Expectations, performance evaluation and consumer's perceptions of quality", Journal of Marketing, 57, pp. 18-34.

TeJEDA Marshall, J. Guillermo (2006), Diccionario crítico del diseño, Barcelona: Ediciones Paidós Ibérica, p. 174.

TUdela, Fernando (1985), Conocimiento y diseño, México: UAM Xochimilco, pp. 41, 47.

VILADÀs, Xènia (2008), Diseño rentable, diez temas a debate, Barcelona: Indexbook, p. 123.

VILCHIS, Luz del Carmen (2000), Metodología del diseño. Fundamentos teóricos, México: UNAM, p. $25,45,54,73,89,107,126$.

(1999). Diseño. Universo de conocimiento, México: UNAM, p. 28, 115, 139, 161.

WestbrooK, R. A. (1980b), "A rating scale for measuring product/service satisfaction", Journal of Marketing, 44, pp. 68-72.

Williams, Christopher (1984). Los origenes de la forma, Barcelona: Gustavo Gili, pp. 76, 108.

WoLf, Laurent (1972), Ideología y producción. El diseño, Barcelona: A. Redondo Editor (Colección beta), p. 93.

ZIMMERMAN, Yves (1998), Del diseño, Barcelona: Gustavo Gili, p. 135. 